\title{
The Puzzling Persistence of Unenforceable Contract Terms
}

\begin{abstract}
Charles A. SullivaN
Contracts frequently contain clauses that are not enforceable-at least, not enforceable as written. While mistake may explain some such clauses, invalid terms are often used by sophisticated actors who are well aware that they are unenforceable as written. Presumably, this is because such clauses have utility for those who impose them, and the most obvious reason is that the other party to the contract (or, conceivably, some third party) does not realize the clause is unenforceable as written or is unwilling to risk the resources needed to establish its invalidity.
\end{abstract}

The phenomenon seems especially acute in the employment context where, among other instances, it surfaces in connection with overbroad noncompetition clauses and arbitration agreements containing invalid waivers of substantive or procedural rights. It seems likely that large numbers of employees work under agreements that, if challenged, would be found unenforceable as written.

This Article demonstrates that, contrary to some claims, the phenomenon is not constrained by market forces on employers, including the costs of lost opportunities, reputational harms, foregone transactions, or increasing the price of labor. This market failure is in large part due to the judicial approach to such clauses. Once having declared them unenforceable as written, the courts generally proceed to tailor the terms so that they pass judicial muster. The result is to remove the major incentive the law could offer to draft permissible clauses-the risk that the entire clause will fail.

This Article surveys some of the possible solutions to the problem, concluding that none is satisfactory. It urges, however, that a strong step in the right direction would be for courts, once they found a clause to have unenforceable provisions, to widen the angle of their review to consider not only doing justice between the parties before them but, more broadly, considering the interests of uninformed nonparties who are saddled with such provisions.

\section{TABLE OF CONTENTS}

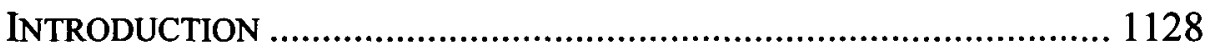

I. WHY INSIST ON AN UNENFORCEABLE CLAUSE? ........................... 1133

II. ARE UNENFORCEABLE-AS-WRITTEN ClaUSES REALLY PROBLEMATIC?

A. Opportunity Costs.

B. Reputational Costs. 


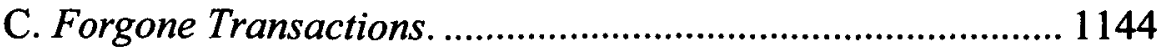

D. Increasing the Price of Labor............................................... 1144

III. UNENFORCEABLE-AS-WRITTEN NONCOMPETE AND ARBITRATION

Clauses

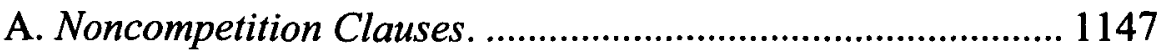

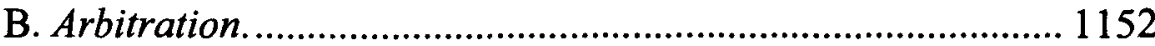

IV. A CLOSER LOOK AT PARTIAL ENFORCEMENT ........................... 1157

V. THE INADEQUACY OF CURRENT APPROACHES ........................... 1162

VI. RETHINKING JUDICIAL HANDS-OFF ...................................... 1170

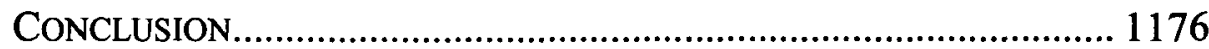

\section{INTRODUCTION}

Contracts frequently contain clauses that are not enforceable 1 -at least, not enforceable as written. ${ }^{2}$ There are few empirical studies of the frequency with which unenforceable-as-written clauses appear in contracts, ${ }^{3}$ but the phenomenon is common enough to raise questions why it persists. ${ }^{4}$ Indeed, it is common enough to have triggered a scattering of legislative responses. ${ }^{5}$

${ }^{1}$ Unlike some other writers, e.g., Juliet P. Kostritsky, Illegal Contracts and Efficient Deterrence: A Study in Modern Contract Theory, 74 IowA L. REv. 115 (1988), I use the terms "unenforceable," "invalid," and the like, rather than "illegal."

2 Some version of these clauses may be enforceable after the court modifies them to eliminate any objectionable terms. See infra text accompanying note 92.

${ }^{3}$ See Curtis J. Berger, Hard Leases Make Bad Law, 74 ColUM. L. REv. 791, 791 (1974) (finding that residential landlords continued to use form leases containing invalid clauses even though they lost a majority of the cases in which such clauses were at issue).

${ }^{4}$ See generally Bailey Kuklin, On the Knowing Inclusion of Unenforceable Contract and Lease Terms, 56 U. CIN. L. REV. 845 (1988); W. David Slawson, Mass Contracts: Lawful Fraud in California, 48 S. CAL. L. REV. 1, 49-51 (1974).

5 See, e.g., UNIF. RESIDENTIAL LANDLORD \& TENANT ACT $\S 1.403$ (b) (1972), 7B U.L.A. 326 (2006) [hereinafter URLTA] ("If a landlord deliberately uses a rental agreement containing provisions known by him to be prohibited, the tenant may recover in addition to his actual damages an amount up to [3] months' periodic rent and reasonable attorney's fees."). Since a tenant would rarely be able to show "actual damages" from the prohibited conduct, the recovery of periodic rent is the most meaningful sanction. The URLTA has been adopted in only a few states, most of which have adopted it without the statutory damage provision. E.g., ALASKA STAT. \$ 34.03.040 (2009); NEB. REV. STAT. $§ 76-1415$ (2008). As the bracketed "[3]" shows, the drafters of the URLTA left it to the adopting states to insert a number, and the two states that have adopted statutory damages have used different numbers. IOWA CODE $\S 562 A .11$ (1979) (three months); ALA. CODE $\S 35-9 A-163$ (1975) (one month). Another example of a statute directed at the phenomenon is treated in the text beginning infra at note 127 . 
It is possible, of course, that such clauses are simply mistakes-attorneys included them in agreements without realizing they are invalid, ${ }^{6}$ and they survive because lawyers (or clients) unthinkingly continue to use forms long after the courts have determined that the clauses at issue are not enforceable. It is also possible that clauses continue to be used, despite having been invalidated by courts or legislatures, because a change in the law is anticipated or at least hoped for. ${ }^{7}$ While some such clauses may continue for these reasons, it seems certain that invalid terms continue to be used by those who are well aware that they are unenforceable as written, presumably because they have utility for those who impose them. The most obvious reason is that the other party to the contract (or, conceivably, some third party) either does not realize the clause is unenforceable as written or is not willing to risk the resources needed to establish its invalidity. ${ }^{8}$

This Article will examine two major areas in which such clauses continue to operate with considerable frequency: first, postemployment noncompetition clauses, where employers often seek broader restrictions than the law allows; ${ }^{9}$ and, second, arbitration clauses, where employers (and others, usually sellers of goods and services to consumers) often seek to add impermissible conditions to otherwise valid agreements to arbitrate. These

${ }^{6}$ See Broadley v. Mashpee Neck Marina, Inc., 471 F.3d 272, 276 (1st Cir. 2006) (striking down an overbroad exculpatory clause without narrowing it to include only negligence: "Any competent lawyer could write a straightforward exclusion of liability for negligence that we would sustain.").

7 "The unenforceable term may be inserted in the legitimate belief that the rule is ripe for change." See Kuklin, supra note 4, at 879 (quoting D. Michael Risinger, Honesty in Pleading and Its Enforcement: Some "Striking" Problems with Federal Rule of Civil Procedure 11, 61 MINN. L. REV. 1, 57 (1976) ("Today's frivolity may be tomorrow's law.")).

${ }^{8}$ See Richard Bales, Normative Consideration of Employment Arbitration at Gilmer's Quinceañera, 81 TUL. L. REV. 331, 380 (2006) (decrying the injustice for "employees who never file[] a claim because they correctly perceive[] that the playing field [is] irrevocably tilted against them, [and] that the cost of leveling the playing field far exceed[s] the value of the underlying claim."); Kurt E. Olafsen, Note, Preventing the Use of Unenforceable Provisions in Residential Leases, 64 CORNELL L. REV. 522, 522 (1979) ("[A] clause with no legal effect can still have tremendous practical effect if the tenant believes that it is binding.").

${ }^{9}$ For example, Catherine L. Fisk, in Reflections on the New Psychological Contract and the Ownership of Human Capital, 34 CONN. L. REV. 765, 782-83 (2002), writes:

In California, covenants not to compete have been unenforceable against employees since 1872. Employers have nevertheless sought to restrict their employees from working for competitors. Employers ask their employees to sign such contracts anyway, presumably counting on their employees to sign such contracts anyway, presumably counting on the in terrorem value of the contract when the employee does not know that the contract is unenforceable. 
are only two of a number of areas where unenforceable-as-written clauses are common. In the employment context alone, other examples include clauses purporting to prospectively waive unwaivable statutory rights; ${ }^{10}$ clauses in releases restricting the ability of employees to file charges with the Equal Employment Opportunity Commission; ${ }^{11}$ and invalid liquidated damages, ${ }^{12}$ choice of law, or choice of forum clauses. ${ }^{13}$ Outside the employment context, the phenomenon arises in the context of residential leases and other consumer transactions especially with respect to waivers of tort liability. ${ }^{14}$

10 See text beginning infra at note 97.

11 See Wastak v. Lehigh Valley Health Network, 342 F.3d 281, 292 (3d Cir. 2003); EEOC v. Cosmair, Inc., 821 F.2d 1085, 1091 (5th Cir. 1987).

12 Stipulated, or liquidated, damages clauses are increasingly being used in the employment setting. See, e.g., Del. Bay Surgical Servs., P.A. v. Swier, 900 A.2d 646, 646 (Del. 2006) (enforcing a liquidated damages clause of $\$ 25,000$ in a doctor's employment contract with a surgical center); Arrowhead Sch. Dist. No. 75 v. Klyap, 79 P.3d 250, 266 (Mont. 2003) (finding that liquidated damages clauses in teaching contracts are almost always enforced as reasonable). Such clauses are unenforceable if they are imposed to compel performance by setting the damages artificially high (compared to likely actual damages) in order to deter breach. See, e.g., Priebe \& Sons, Inc. v. United States, 332 U.S. 407, 413 (1947) (a supposed '“liquidated damages' clause could not possibly be a reasonable forecast of just compensation for the damage caused by a breach of contract. It might, as respondent suggests, have an in terrorem effect of encouraging prompt preparation for delivery. But the argument is a tacit admission that the provision was included not to make a fair estimate of damages to be suffered but to serve only as an added spur to performance. It is well-settled contract law that courts do not give their imprimatur to such arrangements."). See RESTATEMENT (SECOND) OF CONTRACTS $\S 356(1)$ (1981) ("Damages for breach by either party may be liquidated in the agreement but only at an amount that is reasonable in the light of the anticipated or actual loss caused by the breach and the difficulties of proof of loss. A term fixing unreasonably large liquidated damages is unenforceable on grounds of public policy as a penalty."); see also U.C.C. $\$ 2-718(1)$ (2003). The courts routinely enforce normal contract remedies once they determine a stipulated damage clause is in fact a penalty. RESTATEMENT $\S 356$ cmt. a (1981) ("The rest of the agreement remains enforceable, however, under the rule stated in $\S 184(1)$, and the remedies for breach are determined by the rules stated in this Chapter."). See generally Gregory Scott Crespi, Measuring "Actual Harm" for the Purpose of Determining the Enforceability of Liquidated Damages Clauses, 41 Hous. L. REV. 1579 (2005).

13 See Advanced Bionics Corp. v. Medtronic, Inc., 59 P.3d 231 (Cal. 2002). See generally Timothy P. Glynn, Interjurisdictional Competition in Enforcing Noncompetition Agreements: Regulatory Risk Management and the Race to the Bottom, 65 WASH. \& LEE L. REV. 1381 (2008); see also Fisk, supra note 9, at 783 (noting that some out-of-state firms with employees in Califomia try to avoid the effect of California law with choice of forum or choice of law clauses.)

14 As to residential leases, see Berger, supra note 3; Kuklin, supra note 4; as to overbroad exculpatory clauses, see infra note 88 . 
The analysis in this article may have some application to these other settings, but each needs to be examined on its own merits or demerits.

This Article addresses only in passing the question of when noncompetition clauses or restrictive provisions in arbitration agreements are unenforceable: 15 it generally takes the invalidity of particular clauses as given and examines why clauses that are clearly unenforceable as written continue to exist, the consequences of the continued use of such clauses, and what, if anything, the law should do about the phenomenon. Some of the answers it offers are straightforward. First, such clauses continue to be used by one party because of their effects on the other party-either because the other party believes the clauses to be valid or is unwilling to risk violation and the costs of establishing invalidity. Second, the law encourages the use of such clauses by its limited response to them: in contrast to the law's treatment of other kinds of "illegal" contracts which often are not enforceable at all by the more culpable party, ${ }^{16}$ the courts approach this kind of clause far more permissively. Although the clauses are not enforced as written, neither will the courts typically refuse to give them any effect. Rather, they will

15 For example, the Restatement (Second) of Contracts lays out its analytic scheme for enforcement in $\S 178(1)$ :

A promise or other term of an agreement is unenforceable on grounds of public policy if legislation provides that it is unenforceable or the interest in its enforcement is clearly outweighed in the circumstances by a public policy against the enforcement of such terms.

It then proposes multifactor tests to weigh the two interests in $\S 178(2)$ and (3). See generally Alan E. Garfield, Promises of Silence: Contract Law and Freedom of Speech, 83 CORNELL L. REV. 261, 295-99 (1998). The Restatement has more detailed provisions treating particular clauses, including promises in restraint of trade. RESTATEMENT (SECOND) OF CONTRACTS $\$ \S 186-88$. In general, the Second Restatement takes a more flexible approach to the question of the effects of an invalid clause than does the original Restatement of Contracts, which barred enforcement by either contract or restitution, subject to some exceptions. Id. $\S 598$. A number of states continue to use the less flexible approach of the First Restatement. 6 RICHARD A. LORD, WILLISTON ON CONTRACTS $\S 12.4$ (4th ed. 1995) (finding that perhaps a majority of courts still adhere to the First Restatement's view).

16 See generally Kostritsky, supra note 1 . It is common for the courts to describe such agreements as "void," which suggests that such agreements are not merely voidable by the less culpable party but unenforceable by either party; further, "void" may suggest not only that the contract will not be enforced but also that relief such as restitution will be denied. As Professor Kostritsky demonstrates, however, many defective contracts may be enforced by the less culpable party, and actions for restitution for any benefit conferred may or may not be available even if the agreement is not enforceable as a contract. Id. at 118 n.7. See generally Andrew Kull, Restitution's Outlaws, 78 CHI.-KENT L. REV. 17 (2003); John W. Wade, Benefits Obtained Under Illegal TransactionsReasons for and Against Allowing Restitution, 25 TEX. L. REV. 31 (1946). 
typically rewrite the provision to be enforceable or simply enforce the contract without the offending clause. ${ }^{17}$ This results in a disconnect between what is often said to be a primary purpose of declaring some promises against public policy-deterring parties from entering into such arrangements ${ }^{18}$-and the actions of the courts on the ground. In turn, this suggests that the real purpose of the doctrine may be less to deter such conduct than to ensure that courts are not complicit in the prohibited agreements.

But complicity is not so easily avoided. The current approach subordinates deterring such clauses to a perceived overarching imperative to enforce the agreements of the parties-or, at least, to enforce the rest of the agreement of the parties. By thus focusing on "doing justice" to the parties before them, the courts are unwittingly permitting, indeed encouraging, injustice to individuals who are not parties. This Article urges the courts to recognize the unintended consequences of their present policies and therefore take a more rigorous response to the clause before them. ${ }^{19}$ This conclusion is predicated on the notion that courts should be less concerned with reaching the "correct" result in the case before them than in establishing principles that will ensure that justice will be done in the broader class of instances where such clauses are used. The article thus challenges the notion that our current system operates as an efficient deterrence scheme ${ }^{20}$-at least if efficiency includes contracts that do not come to court. ${ }^{21}$ It urges a more

17 See infra notes $99,151 \&$ accompanying text.

18 A classic statement of this reasoning, albeit with respect to a bid-rigging agreement that would clearly be criminal today, is found in McMullen v. Hoffman, 174 U.S. $639,669-70$ (1899):

To refuse to grant either party to an illegal contract judicial aid for the enforcement of his alleged rights under it tends strongly towards reducing the number of such transactions to a minimum. The more plainly parties understand that when they enter into contracts of this nature they place themselves outside the protection of the law, so far as that protection consists in aiding them to enforce such contracts, the less inclined will they be to enter into them. In that way the public secures the benefit of a rigid adherence to the law.

${ }^{19}$ See infra text and notes beginning at note 145 .

${ }^{20}$ See Kostritsky, supra note 1, at 121-22 (arguing in favor of a graduated relief structure when a contract is invalid in order to "maximize efficient deterrence" by "allocating the risk of nonenforcement to the cheapest cost avoider, rather than to both parties in all instances"); $c f$. Walter Gellhom, Contracts and Public Policy, 35 ColuM. L. REV. 679, 684-85 (1935) (arguing for judicial focus on whether enforcement of the atissue contract advances the purposes of the public policy implicated).

${ }^{21}$ Professor Kostritsky recommends that, absent contractual allocation of the risks of nonenforcement, "the courts must make that determination"; they should "allocate the loss to the cheapest cost avoider-the 'superior risk' bearer-if one exists," and 
draconian approach to contracts containing invalid provisions than currently obtains.

This Article proceeds by examining in Part I why parties may insist on clauses that they understand to be unenforceable. Part II then turns to the theoretic question of whether invalid clauses have adverse individual and societal effects, concluding that there is real reason to believe they may. Part III then considers how the law treats two kinds of unenforceable clausesoverbroad noncompetition agreements and arbitration agreements that include unenforceable waivers of substantive rights. Part IV then surveys the inadequacy of current legal approaches to the problem. This sets the stage for Part V, which urges a new judicial approach to such clauses.

\section{WHY INSIST ON AN UNENFORCEABLE ClAUSE?}

Why would one party to a proposed contract insist on a clause in the contract that is unenforceable as written? Let's start with the case of the clause that is entirely unenforceable (in contrast to the clause that is unenforceable as written but is likely to be modified by the court and then enforced). One possibility, of course, is that the party insisting on the clause is mistaken - the clause is unenforceable, but the party insisting on it does not believe that to be true. It could be reasonable or unreasonable in that belief, but its insistence is at least understandable. A variation on this theme is that the insisting party understands that it is very likely that the clause is unenforceable, but believes that the chance of enforceability, while low, is nevertheless worth the gamble. ${ }^{22}$ Where the costs of such insistence are

otherwise "the courts should leave the parties where they are by withholding all judicial aid." Kostritsky, supra note 1, at 123-24. While she notes that "the cases often do not reach the correct results or fail to articulate an adequate theoretical basis," her analysis requires courts to do the judging in the cases before them, and therefore ignores the welfare effects of invalid clauses which never get litigated. Id. at 124.

22 This can be viewed as an application of "real option" theory which might explain the continued existence of such clauses without necessarily justifying them. Real option theory tries to explain, among other things, why lawsuits may be filed when the value of the suit is negative - projected litigation costs exceed the expected value to the plaintiff. See Joseph A. Grundfest \& Peter H. Huang, The Unexpected Value of Litigation: A Real Options Perspective, 58 STAN. L. REV. 1267, 1270-71 (2006) (analogizing a lawsuit to a research project, with the "investors," i.e., the litigants, choosing to make further investments depending on information developed in the earlier stages of the project); see also Robert J. Rhee, The Effect of Risk on Legal Valuation, 78 U. CoLo. L. REV. 193, 194-97 (2007). The theory argues that a lawsuit can be viewed as a series of decision points, each of which allows the plaintiff to assess the prospects of success in light of the costs at that point. While the lawsuit may have "negative value" at the point of filing if all costs will be incurred, the filing of the suit does not commit the plaintiff to incur all those costs, and the decision whether to continue can depend on further information, such as 
slight, perhaps near zero, this might be a rational strategy even if the odds of having the clause finally enforced are minimal. Of course, in this latter scenario, the costs and risks of seeking enforcement, should there later be a breach, must be factored in before the party whom the clause benefits actually files suit. ${ }^{23}$

But perhaps the party seeking the clause is fully aware that it is unenforceable at the outset; that is, it understands there is no chance that a court would enforce the clause in question literally, or such a low chance that it would not be worth the costs of litigation. When would a party nevertheless seek such a clause?

One answer is where the making of the promise-not its legal enforceability-is the point of the exercise. The so-called "gentlemen's agreement" is an example. Although much derided, ${ }^{24}$ the essence of such an agreement is that it depends on the honor of the parties, not the coercive power of the law. ${ }^{25} \mathrm{~A}$ party might seek such a commitment if it thought that

changes in the legal environment that will shift the suit to a positive value. See Scott Moss, Illuminating Secrecy: A New Economic Analysis of Confidential Settlements, 105 MiCH. L. REV. 867, 900-03 (2007). Obviously, this theory suggests that inserting a contract provision creating the possibility of the subsequent lawsuit is yet an earlier decision point that may produce value to the party insisting on it.

$23 \mathrm{Or}$, in real options terms, pursues the litigation past several decision points.

24 "A gentleman's agreement is an agreement which is not an agreement, made between two persons neither of whom is a gentleman, whereby each expects the other to be strictly bound without himself being bound at all." Chemco Leasing SPA v. Rediffusion P.L.C., (1985) 1 F.T.L.R. 201, Q.B. Div'l Ct. (Mr. Justice Vaisey) (citing Sir Robt. Edgar Meggarry). The term was often used to refer to agreements for racial exclusion, see Randall Kennedy, Racial Passing, 62 OHIO ST. L.J. 1145, 1172 (2001) (discussing the 1947 film Gentleman's Agreement (Twentieth Century Fox Film Corp.), in which the hero "is a Christian reporter who exposes and condemns bigotry by posing as a Jew"). The term is sometimes also used to describe baseball's ban of African American players, a ban which was never reduced to writing but was nevertheless ironclad until the Brooklyn Dodgers hired Jackie Robinson in 1947. N. Jeremi Duru, Friday Night 'Lite': How De-Racialization in the Motion Picture Friday Night Lights Disserves the Movement to Eradicate Racial Discrimination from American Sport, 25 CARDOZO ARTS \& ENT. L.J. 485, 530 (2007). Another example is the agreement between the United States and Japan by which Japan would cease to issue passports for its citizens to come to the U.S. and the U.S. would discourage nativist laws aimed at Japanese immigrants. See Keith Aoki, No Right to Own?: The Early Twentieth-Century "Alien Land Laws" as a Prelude to Internment, 40 B.C. L. REV. 37, 48 (1998).

25 Invalid noncompetition clauses might be used by competitors to reduce their compensation costs by signaling to each other that they will not compete for workers. While formal "no hire" agreements between employers who compete with each other may be illegal under the Sherman Act, see Eichorn v. AT\&T Corp., 248 F.3d 131, 132 (3d Cir. 2001) (holding employees had standing to sue for antitrust violation where a nohire agreement directly impeded employee's ability to obtain jobs from at least three 
the other's sense of honor, ethics, morality, ${ }^{26}$ self-interest, ${ }^{27}$ or its fear of reputational consequences in a community whose confidence it needs would lead it to comply regardless of the absence of legal sanctions. ${ }^{28} \mathrm{~A}$ variation on this theme is the use of such clauses as a kind of signaling device-the employer would rather hire workers who do not object to these clauses than

companies); Quinonez v. Nat'l Ass'n of Sec. Dealers, Inc., 540 F.2d 824, 827-28 (5th Cir. 1976) (holding agreement not to hire former employees of a competitor to be an antitrust violation); Union Circulation v. FTC, 241 F.2d 652, 652 (2d Cir. 1957) (finding antitrust violation in no switching agreement restricting hiring for one year), the use by competing employers of noncompetition agreements for each firm's workers may serve the same function without a formal agreement between them.

26 There is some evidence that keeping promises has an independent value for many humans, and some scholars seek to incorporate this view into economic analysis. See, e.g., SteVen Shavell, Foundations of ECONOMIC ANALYSIS of LAW 609 (2004); Eyal Zamir \& Barak Medina, Law, Morality, and Economics: Integrating Moral Constraints with Economic Analysis of Law, 96 CAL. L. REV. 323 (2008).

27 This explains why an agreement may be sought even if the very making of the agreement is sanctionable, such as conspiracies in restraint of trade under the Sherman Act, 15 U.S.C. $\S 1$ (2006), which can subject the parties to criminal liability, $i d$., and suits for treble damages. 15 U.S.C. $\S 15$ (2006). The classic example is price fixing; a successful conspiracy to fix prices depends on, first, a shared perception of the conspirators that each will gain by higher prices and reduced output and, second, a mechanism to detect cheating by the members, which would, of course, destroy the conspiracy. Randall David Marks, Can Conspiracy Theory Solve the "Oligopoly Problem"?, 45 MD. L. REV. 387, 394 (1986) ("To elevate prices or restrict output, and thereby earn supracompetitive profits, firms must accomplish several tasks. First, they must establish a consensus price or price schedules. The greatest threat to the ensuing price-fixing agreement is the urge to cheat. Since the price fixed by the colluding firms is above marginal cost, a firm can charge just under the collusive price and sell additional output. The second task of colluders, therefore, is to enforce the consensus by detecting and punishing cheaters... Unless the structure of the market-or the actions of the colluders-prevents erosion of the collusive price from competition by fringe firms, entrants, and substitute products, the price-fixing agreement will soon deteriorate.").

28 See Lisa Bernstein, Opting out of the Legal System: Extralegal Contractual Relations in the Diamond Industry, 21 J. LEGAL STUD. 115, 135-43 (1992) (detailing how reputational consequences, implemented in part by an arbitration regime, largely drive contract compliance in the diamond trade). In the employment context, an employee might not want to burn bridges with its former employer or get a reputation for ignoring such terms that might affect future employment. 
those who do. ${ }^{29}$ In the contexts with which we are concerned, however, these motives seem secondary at best. ${ }^{30}$

Assuming, however, that the prospect of legal consequences is important, the obvious reason why one party would seek a clause it knew to be unenforceable is that it believed the other party to be unaware of the fact and likely to remain unaware of it. This might be because the second party lacks sophistication and legal counsel. Further, at least in some contexts the insisting party might reinforce the clause's implicit message that it is enforceable as written. ${ }^{31}$ For example, an employer who routinely used overbroad noncompetition clauses, and perhaps occasionally filed suit to enforce them (a suit which might later be settled with a confidentiality clause) $)^{32}$ would reinforce in its workers the belief that the clauses are valid. Empirical evidence that employees are unaware of even their most basic rights-whether their employer needs a good reason to discharge them ${ }^{33}$

${ }^{29}$ See W. Mark C. Weidemaier, The Arbitration Clause in Context: How Contract Terms Do (and Do Not) Define the Process, 40 CreIGHTON L. REV. 655, 658-59 (2007) (discussing the possibility that "employees signal something of value to the employer (nonlitigiousness?)" by signing contracts with clearly unenforceable clause).

30 See Anna Gelpern \& Mitu Gulati, Feel Good Formalism, American University, WCL Research Paper No. 2009-27, available at http://papers.ssrn.com/ sol3/papers.cfm?abstract id $=1474448$ (exploring why lenders use no-modification clauses in sovereign debt instruments when such clauses can have no legal effect).

31 See Rachel Arnow-Richman, Cubewrap Contracts and Worker Mobility: The Dilution of Employee Bargaining Power via Standard Form Noncompetes, 2006 Mich. ST. L. REv. 963, 984 [hereinafter Arnow-Richman, Cubewrap Contracts] (a workplace culture "that convinces its worker that he or she will have only limited options upon termination, not only restricts the power of exit, but also controls the parties' ongoing bargaining process about the terms of their relationship and consequently the overall quality of the worker's employment.").

32 Confidentiality clauses settling litigation are typically enforced by the courts, despite questions about their appropriateness. See generally Moss, supra note 22, at 869 ("Courts regularly allow confidentiality provisions; indeed, under existing law, they cannot force parties to disclose settlement terms they had agreed to keep confidential."); see also Jon Bauer, Buying Witness Silence: Evidence-Suppressing Settlements and Lawyers' Ethics, 87 OR. L. REV. 481, 481 (2008); Minna J. Kotkin, Invisible Settlements, Invisible Discrimination, 84 N.C. L. REV. 927,929 (2006).

33 Pauline T. Kim, Bargaining with Imperfect Information: A Study of Worker Perceptions of Legal Protection in an At-Will World, 83 CORNELL L. REV. 105, 110-11 (1997) (330 unemployed survey respondents "consistently overestimate[d] the degree of job protection afforded by law, believing that employees have far greater rights not to be fired without good cause than they in fact have. For example, although the common law rule clearly permits an employer to terminate an at-will employee out of personal dislike, so long as no discriminatory motive is involved, an overwhelming majority of the respondents- $89 \%$-erroneously believe that the law forbids such a discharge."). See also Zev J. Eigen, The Devil in the Details: The Interrelationship Among Citizenship, 
suggests that it would not be hard to convince employees that an overbroad noncompetition clause is valid (or that a slanted arbitration regime is all they are entitled to). There is also some limited empirical evidence that employers in fact often draft clauses that are not enforceable as written. ${ }^{34}$

Even if the other party obtains appropriate advice (either at the time the contract is entered into or when she is contemplating nonperformance), the mere existence of the clause is itself a deterrent to violating it. After all, the American Rule requires each party to bear its own attorneys fees, and the individual putatively bound by the clause may not be prepared to expend the resources necessary to defend an action brought by the first party. ${ }^{35}$ This is,

Rule of Law and Form-Adhesive Contracts, 41 ConN. L. REV. 381, 381 (2008) ("Preliminary evidence suggests that less educated, lower skilled and lower paid subjects with greater employment dependency are more likely to feel bound by the terms of formadhesive agreements that restrict their resort to law than more educated, higher skilled, and higher paid subjects with less employment dependency.").

34 The author created a data set consisting of all United States district court cases decided in 2006 and reported in Lexis in which a preliminary injunction (or temporary restraining order) was granted or denied for either a noncompetition clause, a nonsolicitation clause, a nondisclosure, or some combination. It includes cases in which the former employee was the defendant and those in which the new employer is sought to be restrained.

The set includes 52 cases. Excluded from the study were opinions that addressed the question but did not either grant or deny the relief sought. Also excluded were cases in which monetary damages were assessed but no injunctive relief was sought. Although the data set may be skewed by the limitation to federal courts and to cases in which Lexis reported an opinion and the focus on a single year, the study suggests some points of interest.

First, looking only at the federal district court cases, half the applications for emergent relief were denied. Of the 52 cases, 26 were denials by district courts. Of course, not all of these denials were based on a determination that the clause in question was unreasonable; the other requirements for preliminary relief-such as irreparable harm-often played a role.

Second, of those 26 applications for emergent relief which were granted by the federal district courts (including one case that denied relief for breach of a nondisclosure agreement while granting it for violation of a noncompete), only 13 cases awarded the relief sought in full. In the remaining 13 cases, the court limited the relief given, typically because the clause at issue was overbroad.

This suggests a very low success rate $(25 \%)$ if success is measured by enforcing the covenant as written. It also suggests a tendency to draft overbroad noncompetition clauses.

${ }^{35}$ See House of Vision, Inc. v. Hiyane, 225 N.E.2d 21, 25 (Ill. 1967) ("To stake out unrealistic boundaries in time and space, as the employer did in this case, is to impose upon an employee the risk of proceeding at his peril, or the burden of expensive litigation to ascertain the scope of his obligation."). 
in a real sense, a game of chicken: ${ }^{36}$ assuming both parties have accurately determined that the clause is unenforceable, the party desiring enforcement would incur substantial costs to achieve nothing and may in fact be subject to sanctions. ${ }^{37}$ Nevertheless, some players of chicken are better than others, and the existence of the (unenforceable) clause may itself deter the other party from the course of action she would otherwise pursue. ${ }^{38}$ Further, it may influence third parties who forego potentially advantageous transactions with the burdened party in order to avoid the risk of litigation. ${ }^{39}$ For example, an employee may pass up a competing job offer (or the rival employer might not make the offer in the first place $)^{40}$ if the existence of the clause suggests that

36 See REBel WITHOUT A CAUSE (Warner Bros. 1955), described by Amitai Aviram, A Paradox of Spontaneous Formation: The Evolution of Private Legal Systems; 22 YALE L. \& POL'Y REV. 1, 34 (2004):

The Chicken game is a game of coordination, not cooperation. Its story is illustrated in the movie Rebel Without a Cause. Jim Stark (actor James Dean) and Buzz Gunderson compete for Judy's love by playing the "chicken-run" game. Jim and Buzz steal two cars, which they race towards a cliff. The first driver to jump out of his car ("chicken out") loses the game; the other driver can then jump out of his car and is considered the winner, gaining Judy's affection and the respect of his peers. A player who fails to jump out of his car in time will run off the cliff with the car and plunge to the ground.

${ }^{37}$ In theory, of course, the party (or at least its attorney) suing on an unenforceable clause may be subject to sanctions under FED. R. CIV. P. 11 or its state analogs, sanctions which may in some circumstances be paid to the other party. This possibility ups the ante for the party seeking to enforce the clause, and it reduces the risk to the burdened party. But, of course, it operates only when suit is filed and therefore has no effect on the strategic use of clauses which are never intended to be enforced in court.

38 One author describes Chicken as exhibiting a number of unusual characteristics:

For one, irrationality is power; one might even say that irrationality is rational. Thus, it has been observed that cantankerousness, anger, and recklessness can be successful strategies in negotiation. So can a "lock-in" or commitment strategy, by which a player ostentatiously binds himself or herself to a potentially selfdestructive course of action, which encourages the other player to give in to avoid the same disastrous result for both. It follows that the mere appearance of cantankerousness, anger, or irrationality, or the credible communication of a "lockin" or commitment strategy, can be effective.

David Crump, Game Theory, Legislation, and the Multiple Meanings of Equality, 38 HARV. J. ON LEGIS. 331, 369-70 (2001).

39 This is most likely with respect to overbroad noncompetition clauses. See infra text accompanying note 80 .

40 In addition to the risk of hiring an employee who might be enjoined from working, and the potential costs of defending such a suit, the rival employer in this scenario has to consider the risk of liability for interference with contract. See, e.g., 
there is risk of a lawsuit. Although the argument is not often made in the context with which we are concerned, in other areas of the law the existence of a potential claim is said to have adverse consequences despite its unenforceability. A prime example might be invalid patents. ${ }^{41}$

\section{ARE UNENFORCEABLE-AS-WRITTEN CLAUSES REALLY PROBLEMATIC?}

A probably apocryphal story has it that engineers demonstrated, to a scientific certainty, that bumblebees can't fly. ${ }^{42}$ One might anticipate that the economist's response to the "problem" of clauses that are unenforceable as written is that they do not exist or, if they do, they are efficient.

Admittedly, in a perfect world, in which each party would have perfect information and there would be no transaction costs, unenforceable clauses would not exist. Since both parties would be aware of the unenforceability of

Revere Transducers, Inc. v. Deere \& Co., 595 N.W.2d 751, 751 (lowa 1999); Kallok v. Medtronic, Inc., 573 N.W.2d 356, 361-62 (Minn. 1998).

41 See Jay P. Kesan \& Andres A. Gall, Why "Bad" Patents Survive in The Market and How Should We Change?-The Private and Social Costs of Patents, 55 EMORY L.J. 61,70 (2006) ("formally demonstrat[ing] that incorrectly issued patents can survive in the market without judicial review, even when the invention is neither novel nor nonobvious."); Mark A. Lemley, Rational Ignorance at the Patent Office, 95 Nw. U. L. REV. 1495, 1516 (2001) ("[W]hen a patentee obtains a patent, the existence of the patent itself sends a powerful signal to competitors: 'stay away.' If patents do indeed have such an inherent 'in terrorem' effect, then issuing bad patents has a real cost to society."); Christopher R. Leslie, The Anticompetitive Effects of Unenforced Invalid Patents, 91 MINN. L. REV. 101, 103-04 (2007) ("Mere possession of an invalid patent can help maintain an illegitimate monopoly even if the monopolist patent-holder takes no affirmative steps to enforce its patent. The fear of infringement litigation can deter entry into the monopolist's market, even if the potential competitor strongly believes that the patent at issue is invalid. Invalid patents can also increase entry costs ....").

Another area of concern is punitive damages, which some claim to have deleterious consequences even when they are rarely imposed inappropriately. See generally Neil Vidmar \& Mary R. Rose, Punitive Damages by Juries in Florida: In Terrorem and in Reality, 38 HARV. J. ON LEGIS. 487 (2001); Exxon Shipping Co. v. Baker, 128 S. Ct. $2605,2624-25$ (2008) ("A survey of the literature reveals that discretion to award punitive damages has not mass-produced runaway awards, and although some studies show the dollar amounts of punitive-damages awards growing over time, even in real terms, by most accounts the median ratio of punitive to compensatory awards has remained less than 1:1. Nor do the data substantiate a marked increase in the percentage of cases with punitive awards over the past several decades. The figures thus show an overall restraint and suggest that in many instances a high ratio of punitive to compensatory damages is substantially greater than necessary to punish or deter.").

42 Ivars Peterson, Flight of the Bumblebee, The Mathematical Ass'N Of AM. ONLINE, Sept. 14, 2003, http://www.maa.org/mathland/mathtrek_09_13_04.html. 
the clause in question, neither would invest even trivial resources in obtaining it. And since the transaction costs in determining its unenforceability would be nonexistent, any clause that was inserted would, legally speaking, disappear.

In our less than perfect world, information availability is asymmetric, which means that the parties may have access to different information. It is certainly conceivable, therefore, that one party-having invested in lawyer resources-will know that a clause is unenforceable while the other party will not. It is true that the cost of obtaining the information may not be very great, at least as compared to much valuable information in the world. But it may nevertheless be high relative to the value apparently at stake. Further, if one of the parties intends to use this information across a wide range of transactions while the other does not, the marginal cost of the use of the information by the better informed party will approach zero.

Much the same is true with respect to transaction costs. If one party insists on an unenforceable clause, the other party-either ex ante the contract or more likely ex post at the point where she is considering whether to breach-may obtain information about the enforceability of the clause at a relatively small cost. But the information obtained is almost certain to be both that the clause is unenforceable as written and that there are costs entailed in establishing unenforceability should the other party bring suit. Of course, the advice might also stress that the party desiring enforcement might, given no prospect of success, not sue. However it will probably be accompanied with advice that (a) the other party may not so view the prospect of success (the absence of perfect information includes absence of information about each party's views); and (b) the other party might conceivably sue merely to inflict the costs of defense on the party contemplating breach - either in revenge or to persuade yet others that breach of even an unenforceable promise is costly. ${ }^{43}$

In short, one party to a contract may find it rational to insist on a clause it knew was unenforceable. To the extent that informational asymmetries and/or the risks of high transaction costs led the other party to comply, the insisting party might obtain, in a relatively costless way, the benefits the law will not allow it to "purchase" in the contract. There are, to be sure, some

43 The last thing the party insisting on an unenforceable clause desires is a court decision declaring its unenforceability. That will tend to correct the misinformation that is the only reason for insisting on the clause in the first place. Further, there is at least the possibility of nonmutual collateral estoppel against Employee B should the employer lose its suit against Employee A. See Alexandra D. Lahav, Bellwether Trials, 76 GEO. WASH. L. REV. 576, 624 (2008) (exploring the requirements of nonmutual estoppel). But a suit does not have to be prosecuted to the point of a court estoppel-generating judgment in order to inflict substantial costs on the defendant. Voluntary dismissal prior to, or at the filing of, a summary judgment motion will suffice. 
countervailing considerations. While these are interrelated, they will be discussed separately since they are often framed as different reasons why employers are constrained in their actions. First, opportunity costs: in some cases, the party insisting on an unenforceable clause will thereby forego obtaining a clause which, although promising less value, is enforceable. Second, reputational costs might discourage favorable transactions by deterring potential employees from even beginning discussions. Third, there is the risk of foregone transactions when the other party will refuse to contract should the clause be a precondition. Fourth, the use of such clauses might require the employer to pay more in compensation to offset the disadvantageous term.

\section{BA. Opportunity Costs}

With respect to the two areas with which we are concernednoncompetition agreements and arbitration agreements-lost opportunity costs in terms of losing a potentially valid clause are possible but usually not great. That is largely because, as we shall see in more detail, the courts rarely invalidate a clause which is unenforceable as written; rather, they modify it to remove objectionable terms and then, as modified, enforce it. Thus, the courts tend to "sever" invalid provisions in arbitration clauses, and enforce the underlying agreement to arbitrate, which means that there is little lost in overreaching. ${ }^{44}$ Much the same is true with respect to noncompetition clauses. "Reasonable" noncompetition clauses are valid, so that an employer who opts for an unreasonable one risks losing the protection it could have obtained by a reasonable clause. But only a few jurisdictions impose this risk to keep employers honest; ${ }^{45}$ most jurisdictions reduce the opportunity cost by either "blue penciling" excessive restraints in such clauses or applying the "partial enforcement" rule. ${ }^{46}$ While such efforts may be limited by the requirement of employer good faith, ${ }^{47}$ we will see that employers intent on gaming the system have little to worry about.

\section{BB. Reputational Costs}

The core idea of reputational costs is simply that employers will forego actions that, while legal, create a negative reputation among present and potential workers; such a reputation will deter qualified workers from taking

\footnotetext{
44 See infra text beginning at note 94.

45 See infra text beginning at notes $79 \& 102$.

46 See infra text beginning at note 103.

47 See infra text beginning at note 106.
} 
or continuing employment and thus hurt production or increase compensation needed to be paid to overcome the adverse reputation. ${ }^{48}$ Much of the literature on reputational costs focuses on whether firms forego "opportunistic" conduct in violation of "implicit" contracts to retain employees over their working lives. ${ }^{49}$ Summarizing this literature, Professor Estreicher writes that "[r]eputation is often offered as a late-appearing deus ex machine explaining why opportunistic behavior by employers . . . is likely to be relatively unimportant."50 As his critique suggests, there are theoretic reasons to doubt the efficacy of reputational consequences as a limit on firm conduct, ${ }^{51}$ and limited empirical work confirms this. ${ }^{52}$ One reason why

48 See, e.g., Richard A. Epstein, In Defense of the Contract at Will, 51 U. CHI. L. REV. 947, 968 (1984) ("The employer who decides to act for bad reason or no reason at all may not face any legal liability under the classical common law rule. But he faces very powerful adverse economic consequences. If coworkers perceive the dismissal as arbitrary, they will take fresh stock of their own prospects, for they can no longer be certain that their faithful performance will ensure their security and advancement. The uncertain prospects created by arbitrary employer behavior is functionally indistinguishable from a reduction in wages unilaterally imposed by the employer. At the margin some workers will look elsewhere, and typically the best workers will have the greatest opportunities."); Benjamin Klein, Transaction Cost Determinants of "Unfair" Contractual Arrangements, 70 AM. ECON. REV. 356, 360-61 (1980) (stating contracts facially appearing one-sided may contain a counterweight in the form of implicit, or reputationally driven, checks on opportunistic behavior).

${ }^{49}$ Michael L. Wachter \& Randall D. Wright, The Economics of Internal Labor Markets, 29 INDUS. REL. 240, 252-53, 256-57 (1990); Edward B. Rock \& Michael L. Wachter, The Enforceability of Norms and the Employment Relationship, 144 U. PA. L. REV. 1913, 1921-27 (1996) (describing the mechanisms by which internal labor markets dampen incentives for opportunistic behavior). Implicit contracts are also a focus of corporate literature although the considerations are very different in that context. See, e.g., John C. Coffee, Jr., Unstable Coalitions: Corporate Governance as a Multi-Player Game, 78 GEO. L.J. 1495 (1990).

${ }^{50}$ Samuel Estreicher, Employer Reputation at Work 1 (NYU School of Law, Public Law Research Paper No. 09-02; NYU Law and Economics Research Paper No. 09-04, 2009), available at http://ssm.com/abstract $=1314257$.

51 Robert Cooter \& Melvin A. Eisenberg, Fairness, Character, and Efficiency in Firms, 149 U. PA. L. REV. 1717, 1726 (2001):

[R]eputation fails to ensure adherence when an opportunity arises to make a large gain, net of reputational costs, by exploiting another's trust. In these circumstances, a calculation of benefits and costs prompts the actor to sacrifice reputation. Similarly, reputation does not deter unfairness when the relevant community cannot detect that an implicit contract was broken.

Cooter \& Eisenberg also stress the limitations of reputation on agent behavior:

As a method of making firm-specific faimess norms effective, reputation is important but imperfect. For example, the existence of an implicit contract and the failure of a superior to honor such a contract are often difficult to demonstrate to 
adverse reputation effects may not be much of a constraint in the employment context is the inability of many workers to understand the effect of the contracts they are required to enter, much less to be able to meaningfully weigh their costs against alternative arrangements by unidentified alternative employers. ${ }^{53}$

third parties. Furthermore, a superior's reputation only imperfectly follows her move to another firm or even her transfer within the firm. A subordinate therefore knows that imperfect information gives superiors significant leeway to break implicit contracts without a loss of reputation.

Id. at 1722; see also David Charny, The Employee Welfare State in Transition, 74 TEX. L. REV. 1601, 1613 (1996) ("Enforcement of these contracts depended on the implicit pressures that forced the firms to treat all workers 'fairly'-i.e., pressures that forced firms not to discriminate against high-risk workers, or workers for whom the insuredagainst risks had eventuated. But the limits on discrimination were both arbitrary and, in a crunch, all-too-readily evaded. As economic pressures raised the incentives for firms to renege on these commitments at the margin, reputational and relational pressures were less likely to induce firms into compliance."); Seth D. Harris, Re-Thinking the Economics of Discrimination: U.S. Airways v. Barnett, the ADA, and the Application of Internal Labor Market Theory, 89 IOWA L. REV. 123 (2003) (questioning the significance of reputational effects in the setting of ADA accommodation); Gillian Lester, Restrictive Covenants, Employee Training, and the Limits of Transaction-Cost Analysis, 76 IND. L.J. 49,64 (2001) ("[T] here is still room for opportunism if the value of exploiting the right to bind the employee equals or exceeds the present discounted value of future returns to having a good reputation. Moreover, ... [ $[\mathrm{t}]$ he rapid structural and identity changes that characterize many modern corporations may undermine the effectiveness of reputation as a way to temper opportunism."); Uri Benoliel, Reputation Life Cycle: The Case of Franchising, Academic Ctr. of Law \& Bus. Working Paper Series, available at http://papers.ssm.com/sol3/papers.cfm?abstract_id=1411777 (exploring the limitations of reputation as a constraint on franchisor opportunism).

52 Professor Michael Selmi concludes that "there was no significant effect on stock prices from either the filing of a [discrimination] lawsuit or the announcement of a settlement, and these findings held true regardless of the nature of the suit or the magnitude of the settlement." Michael Selmi, The Price of Discrimination: The Nature of Class Action Employment Discrimination Litigation and Its Effects, 81 TEX. L. REV. 1249,1260 (2003). This is contrary to conclusions in earlier work, e.g., Joni Hersch, Equal Employment Opportunity and Firm Profitability, 26 J. HUM. RES. 139, 139 (1991) (finding a substantial decrease in firm equity as a result of discrimination lawsuits); see also Chiaki Moriguchi, Did American Welfare Capitalists Breach Their Implicit Contracts During the Great Depression? Preliminary Findings from Company-Level Data, 59 INDUS. \& LAB. REL. REV. 51, 76 (2005) ("[T]he severity of the depression's impact was the primary cause that induced management to abandon corporate welfarism. This breach of implicit contracts in turn led workers to abandon company unionism in favor of industrial unions and to develop explicit contracts that minimized managerial discretion.").

53 Estreicher makes a similar point with respect to violations of implicit contracts: "[T]he behavioral law and economics (BLE) literature suggest that applicants will not do a particularly good job processing information about the firm's record of promise- 


\section{BC. Forgone Transactions}

The third kind of cost is the obvious: the other party may refuse to enter into a contract containing an unenforceable clause. By definition, unenforceable terms enter contracts because the parties agree to them. The party burdened by such a clause may recognize its unenforceability and therefore view it as a non-issue. But suppose the burdened party mistakenly believes the clause to be enforceable, say an employee contemplating signing an overbroad noncompete. Should that party walk away from the deal, the other party has lost a valuable transaction by insisting on that which will do it no good in any event. This possibility, however, seems more theoretical than practical. Most employees seem to sign arbitration and non-competition agreements, with at most a token demurrer. ${ }^{54}$ Further, the risk of forgone transactions can be reduced: an employer, faced with "sales resistance" from an especially valuable individual, can simply reverse fields and strike the offending language. ${ }^{55}$ While such action would erode the benefits of the clause if it became sufficiently widespread, an occasional exception to an otherwise pervasive practice would preserve the deterrence benefits of the clause while avoiding the costs of lost transactions.

\section{Increasing the Price of Labor}

Standard economic theory suggests any employee who believes that the costs of the transaction exceed its benefits would simply refuse employment. Employees who accept such terms, believing them to be enforceable, therefore must find the costs of agreeing to a perceived burdensome clause to be offset by the benefits of the contract. ${ }^{56}$ In other words, imposing a cost (or

keeping. These cognitive limitations are likely to obtain even if we assume information is readily available." Estreicher, supra note 50, at 7.

54 See Quigley v. KPMG Peat Marwick, LLP, 749 A.2d 405, 405 (N.J. Super. Ct. App. Div. 2000) (finding market pressure insufficient to invalidate an arbitration agreement signed by plaintiff as "UD," which to him meant "under duress"). But see Edwards v. Arthur Andersen LLP, discussed infra in the text accompanying note 97.

55 This may not be feasible in certain settings, such as consumer sales where no real negotiations are possible. But in the employment relation setting with which we are concerned, this is clearly a viable alternative.

56 Amow-Richman, Cubewrap Contracts, supra note 31, at 981 ("Assuming parties 'shop around,' or at least understand and evaluate the terms being offered, basic law and economics theory suggests that form contracts are likely to be efficient despite their adhesiveness."); Stewart E. Sterk, Restraints on the Alienation of Human Capital, 79 VA. L. REV. 383, 408 (1993) ("On one view, such concerns are misplaced: an employer could 'coerce' an employee to sign a restrictive covenant only if the employer possessed monopsony power in the market for labor."). 
perceived cost) on the other party would require conferring some benefit in return, such that the resulting bargain would be utility-maximizing for both parties. The fact that one party might later regret it is irrelevant. Indeed, since the party accepting the unenforceable term necessarily extracted a quid pro quo, she would be in the more favorable position. That is, since the term is, by hypothesis, unenforceable, she may keep her benefit and ignore the cost once she learns the truth. She has her cake and eats it, too, once she learns of its invalidity.

So runs the theory. And the theory sometimes operates in practice. In the employment context, this is most likely to be true where a valuable prospective employee is negotiating for a position. But there are certainly many situations where the theory does not seem to be reflected on the ground. Noncompetition agreements, for example, are increasingly being exacted from current employees as a condition of employment - without any benefit being extended (other than the continuation of at-will employment). ${ }^{57}$ While a theoretician can describe this continued employment as satisfying the theory, that might better show the poverty of the theory than prove its accuracy.

For these reasons, the classical economic analysis has been questioned. Professor Arnow-Richman, speaking of non-competition clauses, writes that

57 The issue has arisen frequently when employees challenge noncompetition agreements on the grounds of lack of consideration. Most cases, for example, hold that continued at-will employment is good consideration for a noncompetition agreement and reject any requirement of additional consideration. E.g., Summits 7, Inc. v. Kelly, 886 A.2d 365 (Vt. 2005); Lake Land Employment Group of Akron, LLC v. Columber, 804 N.E.2d 27 (Ohio 2004); Faw, Casson \& Co. v. Cranston, 375 A.2d 463 (Del. Ch. 1977); Daughtry v. Capital Gas Co., 229 So. 2d 480 (Ala. 1969); cf. Davies \& Davies Agency, Inc. v. Davies, 298 N.W.2d 127, 130-31 (Minn. 1980) ("The adequacy of consideration for a noncompetition contract or clause in an ongoing employment relationship should depend on the facts of each case."). Contra James C. Greene Co. v. Kelley, 134 S.E.2d 166 (N.C. 1964); George W. Kistler, Inc., v. O'Brien, 347 A.2d 311 (Pa. 1975). See generally Mark A. Glick, Darren Bush \& Jonathan Q. Hafen, The Law and Economics of Post-Employment Covenants: A Unified Framework, 11 GEO. MASON L. REV. 357, 401 n.244 (2002) (courts commonly hold that no additional consideration is needed); Jordan Leibman \& Richard Nathan, The Enforceability of Post-Employment Noncompetition Agreements Formed After At-Will Employment Has Commenced: The "Afterthought" Agreement, 60 S. CAL. L. REV. 1465, 1478-79 (1987) (finding that promises executed by an employee on threat of dismissal from at-will employment should be unenforceable.); Tracy L. Staidl, The Enforceability of Noncompetition Agreements When Employment Is At-Will: Reformulating the Analysis, 2 EMP. RTS. \& EMP. POL'Y J. 95, $104-07$ (1998) (arguing that noncompetition agreements signed before or during at-will employment should be unenforceable, unless exchanged for job security). Postemployment arbitration agreements have also been upheld against consideration-based challenges. See, e.g., Quigley v. KPMG Peat Marwick, LLP, 749 A.2d 405 (N.J. Super. Ct. App. Div. 2000). 
consumers may be "boundedly rational" in approaching contract terms and unable to accurately assess the impact of such terms on them. She goes on:

It is likely that the same, if not greater, cognitive failures occur when workers assess standardized terms like noncompete agreements. Even if employees legitimately prefer a higher salaried job with a noncompete to a lower paying job with no restraints on competition, there is no reason to assume that an efficient trade has been reached regarding the scope of the restraint, and it may well be that the standardized terms adopted by the employer overreach. ${ }^{58}$

In other words, to the extent that employees are unable to meaningfully assess the costs of the clauses in question, they will be unable to bargain for the kind of compensation that would offset the increased burdens they think they are undertaking. A similar analysis has been undertaken by Professor Matthew Bodie regarding employee assent to arbitration agreements. ${ }^{59} \mathrm{He}$ concludes, "the information necessary to determine the efficiency of a predispute agreement is likely to be unavailable to employees who contemplate such agreements. Faced with this dilemma, employees may fall back onto decisionmaking shortcuts, known as heuristics, which may lead them to an inefficient result." 60

In sum, there seem to be few economic constraints on the use of unenforceable-as-written noncompetes and arbitration clauses. ${ }^{61}$ That is, in large part at least, due to the law's refusal to entirely deny enforcement of such clauses. A closer examination of the governing legal regime will explain why.

58 Arnow-Richman, supra note 31, at 981; see also Russell Korobkin, Bounded Rationality, Standard Form Contracts, and Unconscionability, 70 U. CHI. L. REV. 1203, 1203 (2003).

${ }^{59}$ Matthew Bodie, Questions About the Efficiency of Employment Arbitration Agreements, 39 GA. L. REV. 1 (2004).

$60 \mathrm{Id}$. at 6. Professor Bodie explores a number of cognitive biases, including the optimism bias and framing effects, which operate as heuristics for employees and may result in suboptimal choices. Id. at 33-39.

${ }^{61}$ In these situations, there is an imbalance between the two parties, which may be described in terms of "bargaining power" or status. E.g., Bateman Eichler, Hill Richards, Inc. v. Berner, 472 U.S. 299, 307 (1985) (permitting a "tipee" of inside securities information to sue a "tipper," despite the fact that the tip was illegal). See Kostritsky, supra note 1, at 127-28 (arguing that, in deciding whether to enforce illegal contracts, "[c]ourts should favor the party with inferior status" in the sense of "some disparity in professional stature, as when one party is an expert in the transaction, better educated, or financially better off than the other party."). 


\section{UNENFORCEABLE-AS-WRITTEN NONCOMPETE AND ARBITRATION Clauses}

With both postemployment noncompetition clauses and arbitration agreements, employers often draft language that they know will not be enforced as written. Not coincidentally, in both settings the courts, while refusing to enforce the clause as written, typically enforce a cleaned-up version of it. The effect is to reduce or eliminate any incentive for employers to draft clauses that comply with legal requirements and therefore to encourage future use of exactly the same provision.

\section{A. Noncompetition Clauses}

The law generally requires valid postemployment agreements not to compete to be ancillary to a legitimate transaction or relationship (such as an employment relationship), ${ }^{62}$ to be reasonable in terms of that interest, and not to be outweighed by hardship to the employee or likely injury to the public. ${ }^{63}$ In concrete terms, "reasonable" means that noncompetes must not restrain the employee over a greater area or for a longer period of time than is necessary to protect the employer's legitimate interest, such as protecting confidential information or customer relations. ${ }^{64}$

62 See RESTATEMENT (SECOND) OF CONTRACTS $\$ 187$ (1981) (“A promise to refrain from competition that imposes a restraint that is not ancillary to an otherwise valid transaction or relationship is unreasonably in restraint of trade."); id. $\S 187 \mathrm{cmt}$. b ("The promisee's [legitimate] interest may arise out... of a relation between himself as employer or principal and the promisor as employee or agent."). Section 188(b)(2) expressly approves of "a promise by an employee or other agent not to compete with his employer or other principal."

${ }^{63}$ Section $188(1)$ of the Restatement invalidates employee promises not to compete if:

(a) the restraint is greater than is needed to protect the promisee's legitimate interest, or

(b) the promisee's need is outweighed by the hardship to the promisor and the likely injury to the public.

Id. $\S 188(1)$

64 The seminal article is Harlan M. Blake, Employee Agreements Not to Compete, 73 HARV. L. REV. 625 (1960). Other pieces include: Arnow-Richman, Cubewrap Contracts, supra note 31; Rachel S. Arnow-Richman, Bargaining for Loyalty in the Information Age: A Reconsideration of the Role of Substantive Fairness in Enforcing Employee Noncompetes, 80 OR. L. REV. 1163 (2001); Samuel C. Damren, The Theory of "Involuntary" Contracts: The Judicial Rewriting of Unreasonable Covenants Not to Compete, 6 TEX. WESLEYAN L. REV. 71 (1999) (analyzing cases involving judicial revision); Ronald J. Gilson, The Legal Infrastructure of High Technology Industrial Districts: Silicon Valley, Route 128, and Covenants Not to Compete, 74 N.Y.U. L. REV. 
The efficiency rationale for this regime is typically cast in terms of encouraging employers to share information within the firm ${ }^{65}$ and to invest in training employees. ${ }^{66}$ The former justification parallels to some extent trade secret law, but a valid noncompetition clause avoids the complications and uncertainties of determining whether the departing employee has access to trade secrets, ${ }^{67}$ and, more importantly, whether she will use them in her new employment. ${ }^{68}$ While the law therefore recognizes legitimate reasons for an

575 (1999) (discussing the economic incentives of employers to continue requiring such agreements); Lester, supra note 51; S. Elizabeth Wilborn Malloy, Physician Restrictive Covenants: The Neglect of Incumbent Patient Interests, 41 WAKE FOREST L. REV. 189 (2006); Sterk, supra note 56.

${ }^{65}$ Blake, supra note 64 , at $650-51$ (discussing the need to protect information as organizations grow larger and more complicated).

${ }^{66}$ Lester, supra note 51, at 51 ("Perhaps the most logical way to begin my inquiry is to ask why an employer would want a restrictive covenant to begin with. While there may be a number of answers to this question, the most prevalent concerns the protection of a specific investment" in processes, customers, or training.).

${ }^{67}$ Professor Gilson writes:

A postemployment covenant not to compete prevents knowledge spillover of an employer's proprietary knowledge not, as does trade secret law, by prohibiting its disclosure or use, but by blocking the mechanism by which the spillover occurs: employees leaving to take up employment with a competitor or to form a competing start-up.

Gilson, supra, note 64, at 602-03; see also Catherine L. Fisk, Working Knowledge: Trade Secrets, Restrictive Covenants in Employment, and the Rise of Corporate Intellectual Property, 1800-1920, 52 HASTINGS L.J. 441 (2001).

There is, however, some recent work suggesting that employers should sometimes prefer option contracts to noncompetition agreements because the possibility of leaving the firm generates some incentives for employees that may redound to the benefit of the employer. Matthias Kräkel \& Dirk Sliwka, Should You Allow Your Employee to Become Your Competitor? On Noncompete Agreements in Employment Contracts, 50 INT'L ECON. REV. 117 (2009). This may explain Professor Gilson's argument that California's rejection of noncompetition clauses in employment contracts is an explanation for the success of Silicon Valley. Gilson, supra note 64 at 578; see also Sampsa Samila \& Olav Sorenson, Non-Compete Covenants: Incentives to Innovate or Impediments to Growth (May 28, 2009), http://papers.ssm.com/sol3/papers.cfm?abstract_id=1411172 (empirical research showing that enforcement of noncompetition clauses "significantly impedes entrepreneurship and regional growth").

68 This requirement is alleviated to some extent by the doctrine of "inevitable disclosure." Pepsico, Inc. v. Redmond, 54 F.3d 1262 (7th Cir. 1995). Inevitable disclosure, however, is not often found, and the origins of the doctrine have been critiqued. Alan Hyde, The Story of Pepsico, Inc. v. Redmond: How the Doctrine of Inevitable Disclosure of Trade Secrets in Marketing Sports Beverages Was Brewed, in EMPLOYMENT LAW STORIES (Samuel Estreicher \& Gillian Lester eds., 2007 ). 
employer to seek protection from competition from former employers, ${ }^{69}$ the limitations it imposes reflect a countervailing recognition that illegitimate employer interests may also be served by noncompetition agreements. The most obvious illegitimate interest is simply insulation from heightened competition in the marketplace from the former employee or her new employer.

Less obvious, but perhaps more important, is the effects of such clauses on the retention of, and compensation paid to, present employees. In the past, only the most valuable employees, often those under individual employment contracts, were subject to noncompetition clauses. ${ }^{70}$ Today, however, many at-will employees are also subject to such restrictions, ${ }^{71}$ typically exacted as a condition of hiring or continued employment. ${ }^{72}$ From the employer's perspective, noncompetition clauses tend to restrict employee mobility and thus retain valued workers without the need for a corresponding contractual commitment by the employer. Valid noncompetition clauses tend to deter a firm's employees (or at least the most risk averse of them) from working for a competitor or, indeed, from leaving its employ at all. ${ }^{73}$ As their skills become more industry-specific, employees will have to risk a lawsuit, a period of un- or under-employment, or a shift in career in order to leave. Not only does this tend to keep valued employees in their jobs, but the unavailability or lesser attractiveness of alternative employment should tend

${ }^{69}$ Such clauses may also be involved in other transactions, such as the sale of a business.

${ }^{70}$ Fisk, supra note 67.

71 See supra note 57.

${ }^{72}$ Rachel Arnow-Richman, in Cubewrap Contracts, supra note 31, at 980-81, writes:

That noncompetes are now form documents suggests that employers use them across a range of positions and relationships, and that consequently, large classes of workers within a single organization may be subject to the same restraint. This may mean that employers are overusing noncompetes, and that the standardized restraint is more likely to be overbroad in individual situations. More importantly, the practice sends a message to employees about their employer's expectations and understanding of its rights, which may or may not accord with legal realities. This increases the potential in terrorem effects of noncompetes, making employees more reluctant to leave and limiting their ability to bargain for better terms of employment.

73 Blake, supra note 64 , at $682-83$ ("For every covenant that finds its way to court, there are thousands which exercise an in terrorem effect on employees who respect their contractual obligations and on competitors who fear legal complications if they employ a covenantor, or who are anxious to maintain gentlemanly relations with their competitors. Thus, the mobility of untold numbers of employees is restricted by the intimidation of restrictions whose severity no court would sanction."). 
to depress the compensation the employer needs to pay these "captive" workers. ${ }^{74}$

This is the inevitable effect of a valid noncompete, but such benefits can also flow from an overbroad clause. To the extent that an employee believes it to be enforceable as written, or even thinks that there is a substantial chance that it might be, employee mobility will be restricted. One indicator of this, somewhat counter-intuitively, is the number of cases of clauses found unenforceable as written, ${ }^{75}$ typically because they are too broad. ${ }^{76}$ These are,

${ }^{74}$ See Bradford P. Anderson, Complete Harmony or Mere Detente? Shielding California Employees from Non-Competition Covenants, 8 U.C. DAVIS BUS. L.J. 8,8 (2007) ("E]liminating the ability of an employee to seek employment with a competitor allows an employer to maintain artificially depressed wages and benefits, because if the employee has no realistic employment alternative, then wages need not be competitive"); Sterk, supra note 56, at 410 ("by limiting the number of attractive alternatives available to an employee, a restrictive covenant may ... 'coerce' that employee to remain with his initial employer").

I know of no general empirical work on this phenomenon but one example of it in operation is major league baseball where the elimination of the "reserve clause" (which tied a player to a particular club) led to competition for "free agents" and skyrocketing salaries. ANDREW S. ZIMBALIST, BASEBALL AND BILLIONS 84 (1994) ("Between 1976 and 1991, the first fifteen years of free agency, the real mean salary grew at an annual rate of 13.8 percent, or over seven times the rate of growth of the previous twenty-six years."). The point of this example is not that most workers can expect multi-million dollar contracts; indeed, the shift in baseball seems to have shifted salaries towards the top. Rodney Fort, Pay and Performance: Is the Field of Dreams Barren?, in DIAMONDS ARE FOREVER: THE BUSINESS OF BASEBALL 134, 152-54 (Paul M. Sommers ed., 1992) (noting that free agency has caused baseball salaries to be "skewed toward the top end of the salary scale" and that salary disparity is larger now than it was during the reserve clause period). Rather, it is that elimination of restraints on competition can have significant compensation effects in the market.

${ }^{75}$ E.g., Zambelli Fireworks Mfg. Co. v. Wood, 2:08-cv-415, 2009 U.S. Dist. LEXIS 3974 (W.D. Pa. Jan 21, 2009) (refusing to enforce as written a covenant barring the former employee from engaging "in any manner" in the pyrotechnic business in the continental United States; the court narrowed the restraint, in part because the effect of fully enforcing it would "literally prevent him from engaging in his chosen profession."); G\&K Servs., Inc. v. Ambler, No. 07-601, 2007 U.S. Dist. LEXIS 16106 (E.D. Pa. Mar. 7, 2007) (covenant was reduced from 18 to 12 months and dramatically narrowed geographically when enforcing it as written would exclude the employee from 86 of the top 100 metropolitan areas in the United States and Canada); Coventry First, LLC v. Ingrassia, No. 05-2802, 2005 U.S. Dist. LEXIS 13759 (E.D. Pa. July 11, 2005) (enforcing the covenant for three years but narrowing it from the U.S., Puerto Rico, and Canada to the five states in which the plaintiff did business).

${ }^{76}$ Lester, supra note 51 , at 56 ("The bite of the reasonableness analysis rests principally in the latter factors, pertaining to the scope of the restrictions: a restraint deemed reasonable in scope typically will not be invalidated due to public interest or hardship alone. Conversely, a restraint found to violate public interest or hardship 
by definition, instances of employer overreaching. Further, in most cases, as we will see, the clause is nevertheless partially enforced, thus giving the employer some remedy. ${ }^{77}$ Some invalid clauses may be explained as honest mistakes since the test for validity is sufficiently indeterminate to undercut even good faith and reasonable efforts to draft a valid clause. ${ }^{78}$ But it seems likely that many, perhaps most, reflect the incentives the law has created for employers: ask for as much as possible, with the expectation that you will get at least what you're entitled to should the matter go to court. While some states simply void clauses that they find unreasonable, most states will modify the clause, using either the old "blue pencil" rule or its more modern variant, the "partial enforcement" rule to reform the clause so that it is reasonable. 79

The effects of such clauses on the parties to the contract in question are obvious, but clauses that are unenforceable as written may also have effects on third parties. Most obviously, noncompetition clauses may deter other employers from hiring employees subject to such clauses, ${ }^{80}$ with concomitant

concerns virtually always also contains unreasonable time, geography, or activity constraints.").

${ }^{77}$ It is very unlikely that the use of invalid clauses will trigger any liability for the employer. Although an argument can be made that such clauses violate the federal antitrust laws, at least where they have the requisite effect in a given market-see Harvey Goldschmid, Antitrust's Neglected Stepchild: A Proposal for Dealing with Restrictive Covenants Under Federal Law, 73 ColuM. L. REv. 1193 (1973); Charles A. Sullivan, Revisiting the "Neglected Stepchild": Antitrust Treatment of Postemployment Restraints of Trade, 1977 U. ILL. L.F. 621, 622-23-the courts have never been receptive to such claims. See Cole v. Champion Enters., 496 F. Supp. 2d 613, 635 (M.D.N.C. 2007) (alternative holding rejecting a treble damages claim by a restrained employee because he had neither shown an effect on competition nor that any harm from compliance was "antitrust injury"); DeSantis v. Wackenhut Corp., 793 S.W.2d 670, 687 (Tex. 1990) ("There can be little doubt that the Sherman Act applies to such agreements. However, it appears that no such noncompetition agreement has ever been held to violate the Sherman Act." (citations omitted)).

78 This may be the reason why discharging an employee for refusing to sign a noncompetition agreement that she reasonably believed to be unenforceable has been held not to be actionable under a state whistleblower law. See Maw v. Advanced Clinical Commc'ns, Inc., 846 A.2d 604 (N.J. 2004) (5-2 decision). A contrary result might well occur if the clause were in fact unenforceable. Edwards v. Arthur Andersen LLP, 189 P.3d 285 (Cal. 2008) (holding that requiring an employee to sign a release purporting to waive a nonwaivable right related to employment is actionable); see also RESTATEMENT (THIRD) OF EMPLOYMENT LAW § 4.02(d) (Sept. 24, 2008) (Council Draft No. 3); Richard Bales, Sullivan on Not Waiving the Unwaivable, Jan. 17, 2009, http://lawprofessors.typepad.com/laborprof_blog/2009/01/sullivan-on-not.html.

${ }^{79}$ See text beginning infra at note 102.

${ }^{80}$ Similar issues arise from no-hire agreements between firms, often between a labor supplier and its customer. See Heyde Cos. v. Dove Healthcare, 654 N.W.2d 830, 836 
adverse effects on them and, potentially, on the market. ${ }^{81}$ It is true that, with respect to access to legal advice, such employers are likely to be in a better position to assess the probable enforceability of a noncompete. But, while it has greater access to the law than the typical employee, the prospective employer may well lack enough factual information as to the operations of the prior employer to correctly assess the legality of such a clause. Further, the main source of available factual information for such a judgment is the prospective employee, who is obviously not disinterested 82 and whose limited resources may make any indemnity clause extracted from her as a condition of hire of little value.

\section{B. Arbitration}

A second example of the use of clauses known to be unenforceable as written arises in the context of agreements requiring arbitration of any dispute between the parties. The Federal Arbitration Act $^{83}$ makes such clauses generally enforceable, ${ }^{84}$ but that does not mean that all provisions in

(Wis. 2002) (strictly scrutinizing no hire agreement because its operation was similar in effect to noncompetition agreement); see also Nixon Peabody LLP v. de Senilhes, Valsamdidis, Amsallem, Jonath, Flaicher Associes, 873 N.Y.S.2d 235 (N.Y. Sup. Ct. 2008) (striking down no hire agreement in law firm merger talks as violative of public policy). See generally David J. O'Brien, Note, The Enforceability of No-Hire Provisions in Mergers, Acquisitions, and Other Entrepreneurial Ventures, 3 ENTREPRENEURIAL BUS. L. J. 113 (2008).

81 See supra note 75.

82 For example, the new employer may have to rely on the prospective employee's description of the clients with whom she works or the information to which she has access. There will often be no feasible way to cross-check this independently of the present employer.

839 U.S.C. $\S 1$ et seq. (2006).

84 To be precise, the FAA requires that validity of agreements to arbitrate be determined by the general contract law of the state in question. Doctor's Assocs., Inc. v. Casarotto, 517 U.S. 681, 686-87 (1996) ("[S]tate law may be applied 'if that law arose to govern issues concerning the validity, revocability, and enforceability of contracts generally... What is forbidden is state laws applicable only to arbitration."); see also Southland Corp. v. Keating, 465 U.S. 1 (1984) (holding that Congress intended the FAA to preempt any state laws that would frustrate the federal policy of encouraging arbitration); Circuit City Stores v. Adams, 532 U.S. 105, 122 (2001) (noting criticism of Southland, but declining to undercut it in a case involving the application of the FAA in a federal, rather than in a state, court). As a result, particular agreements may be unenforceable for reasons ranging from failure to meet the offer/acceptance and consideration requirements for all contracts, or be invalidated on grounds such as fraud, duress, and unconscionability. See generally Richard A. Bales, Contract Formation Issues in Employment Arbitration, 44 BRANDEIS L.J. 415 (2006); Jeffrey W. Stempel, Arbitration, Unconscionability, and Equilibrium: The Return of Unconscionability 
arbitration agreements are valid. For example, some "arbitration" regimes may be too slanted to count as such. ${ }^{85}$ Perhaps more common are provisions in agreements to arbitrate that have little to do with arbitration per se. ${ }^{86}$ The Supreme Court has repeatedly stressed that "By agreeing to arbitrate a statutory claim, a party does not forgo the substantive rights afforded by the statute; it only submits to their resolution in an arbitral . . forum."87 Thus, provisions purporting to waive substantive or remedial rights related to employment $^{88}$ are often incorporated in arbitration agreements and, if

Analysis as a Counterweight to Arbitration Formalism, 19 OHIO ST. J. ON DISP. RESOL. $757,766-67$ (2004). The present concern is not with attacks on arbitration agreements per se but rather with particular clause in such agreements that would fail analysis for public policy reasons.

85 Since arbitration is a private method of dispute resolution, an arbitral forum can be whatever the parties choose; indeed, an employer could create an arbitration forum for its own purposes. The obvious risks of bias have led courts to reject so-called arbitration which was slanted too much in favor of the employer. E.g., McMullen v. Meijer Inc., 355 F.3d 485 (6th Cir. 2004) (mandatory arbitration agreement invalid to the extent it gave employer unilateral control over the pool of arbitrators); Dumais v. Am. Golf Corp., 299 F.3d 1216, 1219 (10th Cir. 2002) (as construed, "an arbitration agreement allowing one party the unfettered right to alter the arbitration agreement's existence or its scope is illusory."); Hooters of Am., Inc. v. Phillips, 173 F.3d 933, 938 (4th Cir. 1999) ("Hooters materially breached the arbitration agreement by promulgating terms so egregiously unfair as to constitute a complete default of its contractual obligation to draft arbitration rules and to do so in good faith."); see also Rosenberg v. Merrill Lynch, Pierce, Fenner, \& Smith, Inc., 170 F.3d 1 (1st Cir. 1999) (failure to provide an employee with the arbitration rules of the employer when the arbitration agreement specifically requires the employee to be familiar with such rules is a sufficient basis for striking down the arbitration agreement).

86 See generally Margaret M. Harding, The Redefinition of Arbitration by Those with Superior Bargaining Power, 1999 UTAH L. REV. 857, 862-63:

$[\mathrm{U}]$ nfortunately, we are at the point where, at least when the weaker party has no power to negotiate the existence or the terms of the arbitration clause, the weaker party needs some protection from the use of arbitration. The protection that is needed is not from arbitration in its pure form, but rather from arbitration in its distorted form. Some parties with superior bargaining power are using the arbitration clause to give themselves clear and obvious advantages with respect to both the actual dispute resolution process and the potential underlying claims.

${ }^{87}$ E.g., Preston v. Ferrer, 128 S. Ct. 978, 987 (2008) (quoting Mitsubishi Motors Corp., 473 U.S. 614, 628 (1985)). This language from Mitsubishi has been quoted in several Supreme Court cases involving employment. E.g., Gilmer v. Interstate/Johnson Lane Corp., 500 U.S. 20, 26 (1991).

88 Prospective waivers of substantive rights also arise in the tort context. The Restatement (Second) of Contracts $\S 195(1)$ bars terms "exempting a party from tort liability for harm caused intentionally or recklessly" as against public policy. See, e.g., Royal Ins. Co. of Am. v. Sw. Marine, 194 F.3d 1009, 1016 (9th Cir. 1999) (in admiralty, 
litigated, typically invalidated since most such rights cannot be waived in advance. ${ }^{89}$

The fact that such provisions are contained in an otherwise enforceable agreement to arbitrate does not save them. One example is a clause that limits the appropriate recovery under the antidiscrimination laws, as by barring punitive damages. ${ }^{90}$ Such clauses are prospective waivers of substantive rights and, therefore, are invalid. ${ }^{91}$ Less clear is the question of

"exculpatory clauses do not shield Southwest from liability for gross negligence and, a fortiori, do not shield Southwest from liability for intentional misconduct."). See generally 15-85 CORBIN ON CONTRACTS $\S 85.18$ (2008) ("Courts do not enforce agreements to exempt parties from tort liability if the liability results from that party's own gross negligence, recklessness, or intentional conduct.").

The Restatement, however, allows contractual exemptions from tort liability "for harm caused negligently," declaring them unenforceable only under restrictive conditions (including, interestingly, when "the term exempts an employer from liability to an employee for injury in the course of his employment."). RESTATEMENT (SECOND) OF CONTRACTS $\S 195(2)$ (a); see also id. $\S 195(3)$ ("A term exempting a seller of a product from his special tort liability for physical harm to a user or consumer is unenforceable on grounds of public policy unless the term is fairly bargained for and is consistent with the policy underlying that liability."). But see Tunkl v. Regents of Univ. of Cal., 383 P.2d 441 (Cal. 1963) (invalidating prospective waiver of negligence liability); RESTATEMENT (SECOND) OF TORTS $\S 402 \mathrm{~A}$ (1965) (no disclaimer of strict liability). Even courts that enforce such waivers, however, tend to a stricter standard of clarity than would be true for other contract clauses. E.g., Yauger v. Skiing Enters., 557 N.W.2d 60 (Wis. 1996); see also Older Workers Benefit Protection Act, Pub. L. No. 101-521, 104 Stat. 978 (1990) (codified at 29 U.S.C. §626(f) (2006)) (amending the Age Discrimination in Employment Act to bar prospective waivers of ADEA rights but to permit retrospective waivers under heightened procedural protections); 29 C.F.R. $\$ 1625.22$ (2009).

${ }^{89}$ E.g., Alexander v. Gardner-Denver Co., 415 U.S. 36, 51 (1974) ("[W]e think it clear that there can be no prospective waiver of an employee's rights under Title VII."); see also Cange v. Stotler \& Co., 826 F.2d 581, 594-95 n.11 (7th Cir. 1987) ("The ... prospective waivers of statutory rights tend to encourage violations of the law by notifying the wrongdoer in advance that he or she can act with impunity."). Some states have also found prospective waivers of employee rights unenforceable. E.g., Edwards v. Arthur Andersen LLP, 189 P.3d 285 (Cal. 2008) (statutory indemnity rights not waivable by employees). California has a statutory provision declaring that "[a]ny contract or agreement, express or implied, made by any employee to waive the benefits of this article or any part thereof, is null and void." CAL. LAB. CODE $§ 2804$ (2009); see also Overman v. Altama Delta Corp., 193 S.W.3d 540 (Tenn. 2006) (invalidating a prospective waiver of an employee's right to reconsideration of a workers' compensation decision); Davies v. Grossmont Union High Sch. Dist., 930 F.2d 1390 (9th Cir. 1991) (refusing to enforce provision barring party from elective office).

${ }^{90}$ E.g., Weidemaier, supra note 29, at 658-60 (exploring the use of a clause barring punitive damages in arbitration conducted by the American Arbitration Association even though the AAA has a "due process protocol" that would bar such contract terms).

91 See Harding, supra note 86, at 891-911. It is possible that such clauses can be partially justified-for example, a waiver of punitive damages might be unenforceable 
allocation of arbitration fees, but some allocations of fees in arbitration agreements are also unenforceable as written. ${ }^{92}$

In short, some provisions in arbitration agreements are included without much, if any, expectation that they will be enforced in court. ${ }^{93}$ Saliently for

under some set of laws-such as the federal antidiscrimination statutes-but effective under other laws, such as state tort law. Further, where a national employer is using a standardized form, the clause might be effective under some state laws and not others. In such cases, it cannot be said that the clause has no legitimate purpose.

92 Unlike the publicly financed judicial system, arbitration is a private method of dispute resolution, which means that someone must pay the arbitrators. Arbitration agreements often require the employee to pay a portion of the fees, which has generated considerable litigation. The Supreme Court essentially punted in Green Tree Financial Corp. v. Randolph, 531 U.S. 79, 90-91 (2000), suggesting that "[i]t may well be that the existence of large arbitration costs could preclude a litigant such as Randolph from effectively vindicating her federal statutory rights in the arbitral forum." In that case, the agreement was silent as to the allocation of costs, and the Court found "that fact alone [to be] plainly insufficient to render it unenforceable. The 'risk' that Randolph will be saddled with prohibitive costs is too speculative to justify the invalidation of an arbitration agreement." Id.

Prior to Green Tree, several courts had found that some fee allocations were unenforceable. E.g., Shankle v. B-G Maint. Mgmt. of Colo., Inc., 163 F.3d 1230, 1233 34 (10th Cir. 1999) (arbitration agreement requiring the employee to pay a portion of the arbitrator's fees is unenforceable under the FAA; to supplant a judicial forum, arbitration must provide an effective and accessible forum, and the prohibitive cost the employee would have been required to pay meant that the arbitral forum was not accessible); Cole v. Burns Int'l Sec. Servs., 105 F.3d 1465, 1484 (D.C. Cir. 1997) (employers may not require employee to pay arbitrator's fees). But decisions rendered after Green Tree permit fee allocation or at least require some showing that the fees actually impaired the employee's access to the arbitral forum. See, e.g., Cooper v. MRM Inv. Co., 367 F.3d 493, 496-97 (6th Cir. 2004) (remanding for a determination whether the new AAA policy holding employers responsible for most arbitration expenses cast doubt on the district court's determination that plaintiff's arbitration costs were likely to be prohibitively high); Summers v. Dillards, Inc., 351 F.3d 1100, 1101 (11th Cir. 2003) (per curiam) (district court erred in not ordering arbitration because the fee-shifting clause might harm the employee; its concerns were too speculative since plaintiff might prevail at arbitration and could seek judicial review of the award if available remedies were reduced); Musnick v. King Motor Co. of Fort Lauderdale, 325 F.3d 1255, 1259 (11th Cir. 2003) (mere existence of a fee-shifting provision does not render the arbitration agreement unenforceable); Bradford v. Rockwell Semiconductor Sys., 238 F.3d 549, 557-58 (4th Cir. 2001) (fee-splitting does not automatically render an arbitration agreement unenforceable); Blair v. Scott Specialty Gases, 283 F.3d 595, 609 (3d Cir. 2002) (employee who claimed that the cost of arbitrating her employment discrimination claims would be prohibitive was permitted to conduct discovery to determine what it would cost to arbitrate her claims). See generally Bodie, supra note 59; Michael H. LeRoy \& Peter Feuille, When Is Cost an Unlawful Barrier to Alternative Dispute Resolution? The Ever Green Tree of Mandatory Employment Arbitration, 50 UCLA L. REV. 143 (2002). 
present purposes, and similar to the jurisdictions that enforce whittled-down noncompetition clauses, the approach to overreaching in the arbitration context among those courts that have addressed the issue is to sever the unenforceable provisions while continuing to require arbitration. ${ }^{94}$ In light of

${ }^{93}$ A caveat is in order: while the law views some clauses as unenforceable, it is not clear when the court or arbitrator will make that decision. Buckeye Check Cashing, Inc. v. Cardegna, 546 U.S. 440, 446 (2006), found an arbitration agreement to be severable from the contract of which it was a part but did not address the question of whether the arbitration agreement itself may have portions that are severable. See Scovill v. WSYX/ABC, Sinclair Broad. Group, Inc., 425 F.3d 1012, 1019-20 (6th Cir. 2005) (district court was required to invalidate a cost-shifting provision rather than leaving that decision to the arbitrator); $c f$. Great W. Mortgage Corp. v. Peacock, 110 F.3d 222, 231 (3d Cir. 1997) ("Any argument that the provisions of the Arbitration Agreement involve a waiver of substantive rights afforded by the state statute may be presented in the arbitral forum. It would be anomalous for a court to decide that a claim should be referred to an arbitrator rather than a court, and then, by deciding issues unrelated to the question of forum, foreclose the arbitrator from deciding them."). If arbitrators do so, it is not clear whether they can be expected to implement public policy in the same way as judges. Thus, a party may insist on an "unenforceable" clause in an arbitration agreement because it expects it to be enforceable by the arbitrator.

94 The circuits tend to sever, enforcing the arbitration clause while striking down the invalid clauses. Jackson v. Cintas Corp., 425 F.3d 1313, 1317 (11th Cir. 2005) (while provision in arbitration agreement limiting time to bring claims was unenforceable, the severability clause required ordering arbitration with the clause stricken); Booker $v$. Robert Half Int'l, Inc., 413 F.3d 77, 85 (D.C. Cir. 2005) (severing the punitive damages bar and otherwise enforcing the arbitration clause was proper when the agreement contained a severability clause and it contained only one discrete illegal provision); Hadnot v. Bay, 344 F.3d 474, 478 (5th Cir. 2003) (arbitration provision of employee's contract enforceable after the ban on the arbitrator's authority to award punitive damages under Title VII was stricken); Spinetti v. Serv. Corp. Int'l, 324 F.3d 212, 214 (3d Cir. 2003) (agreement to arbitrate was enforceable after attorney fee and costs provision that violated case law and federal statutes was severed because "[y]ou don't cut down the trunk of a tree because some of its branches are sickly."); Gannon v. Circuit City Stores, Inc., 262 F.3d 677, 683 (8th Cir. 2001) ("Severing the punitive-damages clause is consistent with the terms of the contract, the intent of the parties, Missouri contract law, and the FAA's policy favoring the enforcement of arbitration agreements."). But see Alexander v. Anthony Int'l, L.P., 341 F.3d 256, 271 (3d Cir. 2003) ("The cumulative effect of so much illegality prevents us from enforcing the arbitration agreement. Because the sickness has infected the trunk, we must cut down the entire tree."); Ingle v. Circuit City Stores, Inc., 328 F.3d 1165, 1171-73 (9th Cir. 2003) (procedurally and substantively unconscionable provisions of pre-employment arbitration agreement not severable because they overwhelmingly and unconscionably favored employer); Morrison $v$. Circuit City Stores, Inc., 317 F.3d 646, 670-72 (6th Cir. 2003) (agreement limiting punitive damages rendered the arbitration agreement unenforceable). One court tried to reconcile its prior precedents without the infected tree imagery:

The existence of multiple unconscionable provisions will not always evidence "serious moral turpitude" or serious misconduct, precluding enforcement of the 
this, there is little risk to including unenforceable-as-written clauses and potential benefits for those who take them at face value and forego arbitration. ${ }^{95}$

\section{A Closer LoOK AT PARTIAL ENForCEMENT}

This suggests that the law seems largely to ignore the extraction of objectionable clauses - beyond refusing to enforce them as written. The mere existence of such a clause is rarely a basis for refusing to enforce the contract in which they are contained; courts normally delete or edit such clauses and enforce the unobjectionable remainder of the contract. ${ }^{96}$ Further magnifying the problem, courts sometimes "interpret" a clause to avoid the invalidity that would result in the face of clear language to the contrary. For example, in Edwards v. Arthur Andersen $L L P, 97$ the California Supreme Court recognized that a clause that purported to waive employees' right to statutory

agreement to arbitrate. That will depend on whether the number of such provisions and the degree of unfairness support the inference that the employer was not seeking a bona fide mechanism for dispute resolution, but rather sought to impose a scheme that it knew or should have known would provide it with an impermissible advantage.

Parilla v. IAP Worldwide Servs. VI, Inc., 368 F.3d 269, 289 (3d Cir. 2004).

Professor Alan Scott Rau, in Everything You Really Need to Know about "Separability" in Seventeen Simple Propositions, 14 AM. REV. INT'L ARB. 1, 59-74 (2003), argues that generally the arbitration clause should be enforced and the arbitrators should be entrusted with the striking of clauses that are contrary to governing law: "it should only be in the most narrowly delimited class of cases that claims of 'illegality' or 'unconscionability' must be reserved for judicial decision. These are the cases in which the putative defect is 'wrapped up,' or 'enmeshed,' in the very process of arbitration-to the point indeed that it would be difficult even to imagine a tribunal able to reconstitute itself by setting the offending provision aside." Id. at 67. But see Harding, supra note 86 at 939-47 (arguing in favor of invalidating arbitration agreements with unenforceable terms); Clyde Summers, Mandatory Arbitration: Privatizing Public Rights, Compelling the Unwilling to Arbitrate, 6 U. PA. J. LAB. \& EMP. L. 685, 729-31 (2004) (identifying strong reasons for not severing).

95 A similar result obtained in Oubre v. Entergy Operations, Inc., 522 U.S. 422 (1998), where the Court invalidated an attempted waiver of ADEA claims for failure to meet statutory requirements; it did not, however, indicate that the underlying contract was inoperative in other aspects. $I d$. at 427-28 ("Since Oubre's release did not comply with the OWBPA's stringent safeguards, it is unenforceable against her insofar as it purports to waive or release her ADEA claim. As a statutory matter, the release cannot bar her ADEA suit, irrespective of the validity of the contract as to other claims.").

96 See infra note $101 \&$ accompanying text.

97189 P.3d 285 (Cal. 2008). 
indemnification would be unenforceable. ${ }^{98}$ But it simultaneously interpreted language purporting to release Andersen from "any and all" claimsincluding "claims that in any way arise from or out of, are based upon or relate to [Edwards's] employment by, association with or compensation from" Andersen-not to include (and thus purport to waive) statutory indemnity rights. ${ }^{99}$ While narrowly construing employee waivers might seem in general to be preferable, Edwards actually rewards the overbroad drafter by reading the clause more narrowly than it was written: the plaintiff was not hired by a successor company because he refused to sign the contract; he was therefore put in a situation of seeming to waive unwaivable rights without any assurance that, as ultimately happened, that clause would be read not to reach those rights. ${ }^{100}$

The obvious question is why the courts struggle to enforce some version of an unenforceable-as-written clause. Perhaps the most extended discussion of the effects of overreaching clauses has been with respect to overbroad covenants not to compete. ${ }^{101}$ While some jurisdictions adopt an all or nothing approach, ${ }^{102}$ most are more permissive. They start from the proposition that

98 Id. at 294 95. Edwards is better known for its rejection of the Ninth Circuit's interpretation of California law as permitting "partial restraints" in the employment context. See generally Mark A. Lemley \& James H.A. Pooley, California Restrictive Covenants after Edwards (Nov. 4, 2008), available at http://ssm.com/abstract=1295606.

99189 P.3d at 289. See infra note 131 \& accompanying text.

100 Some might argue that this result is defensible on the "no harm, no foul" principle: since plaintiff's stance depended on the clause being invalid, he would have been in no worse position had he signed the contract and then claimed his agreement was ineffective. But from Edwards's perspective, he was being asked to give up a right to indemnity, potentially worth millions of dollars, in return for at-will employment. Even if there was slight risk of enforceability, the deal might well have seemed a bad bargain.

101 The competing considerations regarding invalid terms in arbitration agreements largely track those for noncompete agreements-a desire to implement the intent of the parties to the maximum extent consistent with not depriving the parties of rights that may not be waived in advance. See supra note 94.

102 E.g., Bendinger v. Marshalltown Trowell Co., 994 S.W.2d 468, 473 (Ark. 1999) ("The contract must be valid as written, and the court will not apportion or enforce a contract to the extent that it might be considered reasonable."); Reddy v. Cmty. Health Found. of Man, 298 S.E.2d 906, 916 (W. Va. 1982) ("Where savage covenants are included in employment contracts so that their overbreadth operates, by in terrorem effect, to subjugate employees unaware of the tentative nature of such a covenant, we will find the covenant void."); see also WIS. STAT. ANN. § 103.465 ("Any covenant, described in this subsection, imposing an unreasonable restraint is illegal, void and unenforceable even as to any part of the covenant or performance that would be a reasonable restraint."). But see Star Direct Inc. v. Dal Pra, 767 N.W.2d 898, 916 (Wis. 2009) ("the legislative history and text of the statute do not eliminate or modify the common law rules on divisibility. The statute's prescriptions support this as they apply to any 
the intent of the parties should be honored if possible. ${ }^{103}$ The first step in the direction of liberality was the "blue pencil" rule, which in its strictest manifestations allowed excision of portions of the clause, provided the covenant remained grammatically coherent once its unreasonable provisions were removed. ${ }^{104}$ The theory was, apparently, that such limited excision did

'covenant,' not to the whole employment contract. It specifies that if a restraint is unreasonable, the rest of that covenant is also unenforceable.")

In Georgia, Richard P. Rita Personnel Services International, Inc. v. Kot, 191 S.E.2d 79,81 (Ga. 1972), rejected any modification to an invalid clause to make it enforceable, but this holding has been overturned by statute. See Ferrero v. Associated Materials, Inc., 923 F.2d 1441, 1447 (11 th Cir. 1991).

103 See Wied v. TRCM, LLC, 698 So. 2d 685, 689 (La. Ct. App. 1997):

Nullity of a provision does not render the whole contract null unless from the nature of the provision or the intention of the parties, it can be presumed that the contract would not have been made without the null provision. There has been no such showing here. Indeed, the severability clause, $\S 13$, shows a clear intent of the parties to allow the remainder of the contract to remain in force to the fullest extent permitted by law even if one or more provisions of the contract-such as the noncompetition clause-is declared invalid.

See also infra notes 153-60 \& accompanying text.

Another justification sometimes offered was that the all-or-nothing rule had the unintended consequence of leading courts to enforce covenants that might, strictly speaking, be invalid. Solari Indus., Inc. v. Malady, 264 A.2d 53, 60 (N.J. 1970) ("In some instances, judges have upheld sweeping noncompetitive agreements in circumstances which suggest that, if their equitable power to do so had been recognized, they would have cut them down to satisfy the particular needs at hand.").

${ }^{104}$ E.g., Valley Med. Specialists v. Farber, 982 P.2d 1277, 1286 (Ariz. 1999) ("Here, however, the modifications go further than cutting grammatically severable portions. The court of appeals, in essence, rewrote the agreement in an attempt to make it enforceable. This goes too far."); Licocci v. Cardinal Assocs., Inc., 445 N.E.2d 556, 561 (Ind. 1983):

[I] f the covenant as written is not reasonable, the courts may not create a reasonable restriction under the guise of interpretation, since this would subject the parties to an agreement they had not made. However, if the covenant is clearly separated into parts and some parts are reasonable and others are not, the contract may be held divisible. The reasonable restrictions may then be enforced.

(citations omitted); Deutsche Post Global Mail, Ltd. v. Conrad, 116 F. App'x 435, 439 (4th Cir. 2004) (applying Maryland law):

If a restrictive covenant is unnecessarily broad, a court may blue pencil or excise language to reduce the covenant's reach to reasonable limits. However, under the blue pencil rule, a court may not rearrange or supplement the language of the restrictive covenant. A court can only blue pencil a restrictive covenant if the offending provision is neatly severable.

(citations omitted). 
not amount to making a new contract for the parties. ${ }^{105}$ This was superseded in most jurisdictions by an even more relaxed "partial enforcement" rule (confusingly sometimes also referred to as a blue pencil approach), ${ }^{106}$ which modifies the clause to be reasonable without regard to grammatical niceties. Either approach was typically framed in terms of "severing" the objectionable parts and enforcing the rest. This allowed the court to justify its actions in terms of the parties' intent: they had agreed to the language the court was enforcing (even if they had also agreed to broader language which was severed). ${ }^{107}$

In short, the modern "partial enforcement" rule abandons both the nonenforcement approach and formalistic blue-pencil limitations by fashioning injunctions restricting competition only to a permissible extent. One justification, admittedly of stupefying naiveté, is that employers will not even attempt to overreach:

Appellee argues that adoption of a rule of reasonableness would allow employers to dictate restraints without fear, knowing that judges will rewrite contracts if they are taken to court. Such a contention is without

\section{15-80 CORBIN ON CONTRACTS $§ 80.26$ (2008):}

If the parties have so worded the promise so that the excessive restraint can be eliminated by crossing out a few of the words with a blue pencil, while at the same time the remaining words constitute a complete and valid contract, the court can blue-pencil the contract and enforce it as edited.... By some occult process, the courts adopting this rule have convinced themselves that enforcement without the aid of a blue pencil would be making a new contract for the parties while enforcement in the wake of a blue pencil is not.

106 E.g., Davies \& Davies Agency, Inc. v. Davies, 298 N.W.2d 127, 131 n.1 (Minn. 1980) (referring to Bess v. Bothman, 257 N.W.2d 791 (Minn. 1977), as "adopt[ing] the 'blue pencil doctrine,' which allows a court to modify an unreasonable noncompetition agreement and enforce it only to the extent that it is reasonable" (citation omitted)); see also Kenneth R. Swift, Void Agreements, Knocked-Out Terms, and Blue Pencils: Judicial and Legislative Handling of Unreasonable Terms in Noncompete Agreements, 24 HOFSTRA LAB. \& EMP. L.J. 223, 245 (2007) (describing as separate approaches "using the 'Blue Pencil' doctrine to eliminate an unreasonable term, and using the 'Blue Pencil' doctrine to eliminate an unreasonable term and replace it with a reasonable term."); Griffin Toronjo Pivateau, Putting the Blue Pencil Down: An Argument for Specificity in Noncompete Agreements, 86 NEB. L. REV. 672, 683-88 (2008).

107 Jak Prods., Inc. v. Wiza, 986 F.2d 1080, 1087 (7th Cir. 1993) ("If the covenant is not reasonable as written, the court may not create a reasonable restriction under the guise of interpretation, since this would subject the parties to an agreement they had not made. However, if the covenant is clearly separated into parts and some parts are reasonable and others are not, the contract may be held divisible."). 
merit. Most employers who enter contracts do so in good faith, and seek only to protect legitimate interests. ${ }^{108}$

The court goes on, entirely missing the point, "In fact, relatively few employment contracts reach the courts." 109

Other courts taking the same partial enforcement approach at least recognize the perverse incentives created by this rule and claim to deal with the problem by limiting enforcement to instances where the overbreadth is an innocent mistake; courts taking this view refuse to enforce clauses that they view as intentionally overreaching. ${ }^{110}$ While not rejecting the risks of employer's gaming the system, the decisions have expressed confidence in courts' ability to detect such efforts:

Appellants warn against this Court recognizing the authority of a trial court to exercise any authority in modification of ancillary restrictive covenants, contending that such a rule would be an invitation to in terrorem tactics by employers. The appellants urge that since an employer usually enjoys a

\footnotetext{
108 Raimonde v. Van Vlerah, 325 N.E.2d 544, 547 (Ohio 1975).

109 Id.

110 Durapin, Inc. v. American Products, 559 A.2d 1051, 1058-59 (R.I. 1989) adopts
} a rule

that permits unreasonable restraints to be modified and enforced, whether or not their terms are divisible, unless the circumstances indicate bad faith or deliberate overreaching on the part of the promise.... [E]quity should not permit the injustice that might result from the total rejection of a covenant merely because the court disagrees with the promisee's judgment about what restriction is necessary to protect the promisee's proprietary interests and that covenant's language does not lend itself to the mechanical blue-pencil modification.

See also Westwind Techs., Inc. v. Jones, 925 So. 2d 166, 174 (Ala. 2005) (See, J., concurring): ("The middle view, that a court should in general reform an overbroad noncompetition clause, but should refuse to do so when the clause demonstrably was not drafted in good faith, thus appears to offer a balanced response to the problem of overbreadth."); Data Mgmt., Inc. v. Greene, 757 P.2d 62, 64 (Alaska 1988) ("If an overbroad covenant not to compete can be reasonably altered to render it enforceable, then the court shall do so unless it determines the covenant was not drafted in good faith."); Smith, Batchelder \& Rugg v. Foster, 406 A.2d 1310, 1311 (N.H. 1979) (courts will reform overbroad restrictive covenants if the employers show that they acted in good faith); Solari Indus., Inc. v. Malady, 264 A.2d 53, 56 (N.J. 1970):

When an employer, through superior bargaining power, extracts a deliberately unreasonable and oppressive noncompetitive covenant he is in no just position to seek, and should not receive, equitable relief from the courts.... However, an employer may act in full good faith and nonetheless may still find that the terms of the noncompetitive agreement are later judicially viewed as unnecessarily broad. 
superior bargaining position, onerous covenants will be included in employment contracts leaving a reasonable position for employers to retreat in the event of litigation. However, we are not convinced of the validity of this proposition. Whenever evidence of conscious overreaching, bad faith, monopolization or deliberate oppression is shown, an employer will be denied equitable relief in seeking enforcement of the agreement. ${ }^{111}$

This requirement is sometimes reinforced by decisions holding that the employer has the burden of proof of good faith. ${ }^{112}$ Although the Second Restatement adopts this view, ${ }^{113}$ it does not appear to have done so on the basis of any empirical proof that the courts are able to, or rigorous in, policing overreaching in these circumstances.

The lessons drawn are relatively plain: even where contracts law declares certain agreements to be unenforceable, there are limited incentives for not seeking such an agreement. While it will not be enforceable per se, the other party may honor it for reasons ranging from a personal moral commitment, to a misunderstanding of its legality, to unwillingness to risk the resources necessary to establish its unenforceability. Further, the legal risks of a party employing these kinds of unenforceable clauses appear to be minimal. In most cases, the worst that will happen is that the clause will not be enforced at all. But the worst rarely happens. By such devices as interpretation and blue penciling, courts will provide the insisting party with the protection that it could have had had it not overreached. In the vast majority of cases, the party seeking the clause will have its cake, with the prospect of eating it, too.

\section{THE INADEQUACY OF CURRENT APPROACHES}

As we have seen, the law deals with the problem of unenforceable-aswritten clauses by half-measures. Nonenforcement of offending clauses is the dominant "solution," to which we will return shortly, perhaps because

111 Ins. Ctr. v. Taylor, 499 P.2d 1252, 1255 (Idaho 1972). Other judges have not been so optimistic. E.g., Valley Med. Specialists v. Farber, 982 P.2d 1277, 1286 (Ariz. 1999) ("For every agreement that makes its way to court [and therefore can be modified] many more do not. Thus, the words of the covenant may have an in terrorem effect on departing employees."); see also 6 RICHARD A. LORD, WILLISTON ON CONTRACTS $\$ 13.22$, at 813-14 (4th ed. 1995) (collecting opinions, often in dissent, decrying the perverse incentives created by allowing courts to enforce "good faith" overbroad clauses as modified to be reasonable).

112 E.g., Data Mgmt., Inc. v. Greene, 757 P.2d 62, 64 (Alaska 1988) ("The burden of proving that the covenant was drafted in good faith is on the employer.").

113 RESTATEMENT (SECOND) OF CONTRACTS $§ 184$; see also infra note 157 \& accompanying text. The draft Restatement of Employment Law is struggling with this question. See infra note 176. 
contract law otherwise seems ill-adapted to dealing with the phenomenon. This is partly because of the conceptual gymnastics required to turn the insertion of an unenforceable clause into a contract (by definition, an act assented to by the other party) into a breach of that very contract. Further, contract law's normal expectation damage remedy presents its own challenges. The mere existence of an invalid clause causes no harm, which means that any harm follows only from the plaintiff's abiding by it, ${ }^{114}$ and the mitigation principle may prevent recovery of such harm since plaintiff could, by hypothesis, simply have ignored the clause. ${ }^{115}$

Tort relief also seems problematic. The most obvious traditional tort ${ }^{116}$ in this situation would be "deceit," which allows a damage suit for a misrepresentation of fact or law. 117 The argument would be that the inclusion of the clause in the contract at the imposing party's request amounted to a (mis)representation that it was enforceable. 118 But this requires finding a

114 Professor Kuklin argues that, other than rescission, contract remedies have little to offer since the damages suffered by the victims will rarely be measurable. Kuklin, supra note 4, at 886-88. The result seems correct, but the reason seems wrong. Putting aside the theoretical question of how a clause in a contract could breach that contract, the damages would seem to be the lost opportunity cost of the forgone employment, which should be ascertainable in many circumstances. Indeed, Kuklin examines this possibility under the heading of tort damages. Id. at 888-89.

115 RESTATEMENT (SECOND) OF CONTRACTS § 350(1) (1981) ("Damages are not recoverable for loss that the injured party could have avoided without undue risk, burden or humiliation."). If Professor Kuklin is right, it is probably because of the mitigation requirement.

116 Professor Kuklin also explores the prima facie tort, supra note 4, at 905-11, but that creature is even less viable today than when Kuklin wrote. Ellen M. Bublick, Economic Torts: Gains in Understanding Losses, 48 ARIZ. L. REV. 693, 705 (2006):

The biggest problem with that approach is that intentionally caused economic loss, unlike intentionally caused physical injury, is generally not wrongful. Instead, intentionally caused economic harm is often justified, as in the case of most business competition. As such, the prima facie tort, like an open-mouthed whale taking in plankton, would ingest too much. Consequently, very few states have latched on to the prima facie tort at all, let alone placed it in a significant role.

\section{RESTATEMENT (SECOND) OF TORTS $§ 525$ (1977):}

One who fraudulently makes a misrepresentation of fact, opinion, intention or law for the purpose of inducing another to act or to refrain from action in reliance upon it, is subject to liability to the other in deceit for pecuniary loss caused to him by his justifiable reliance upon the misrepresentation.

118 A misrepresentation of law may be actionable as a statement of opinion where the speaker does not hold the opinion he expresses. $I d$. at $\$ 525 \mathrm{cmt}$. d ("A statement of law ... has the effect of a statement of opinion if it expresses only the actor's judgment as 
clause typically framed as a promise by one party to be a misrepresentation by the other. Further, even assuming that hurdle were jumped, there remains the problem of the reasonableness of the employee's reliance since the injured party must have justifiably relied on the representation to recover. ${ }^{119}$ This could often be difficult to prove from both a factual perspective (did she care about the clause when the contract was entered into?) and a normative one (should she have taken steps to inform herself?). And if these problems could be surmounted, there remains the problem with proving damages, where the mitigation principle again would operate, ${ }^{120}$ although punitive damages could alter the calculation in extreme cases. ${ }^{121}$

Of course, misrepresentation could be a basis to allow the victim to rescind the contract, but that result could be reached by contract law on the grounds of public policy without the contortions required to find misrepresentation in the overreaching in question. Further, should misrepresentation be the basis for rescission, contract law standards for

to the legal consequence that would be attached to the particular state of facts if the question were litigated.").

119 See, e.g., Leonard v. Dorsey \& Whitney LLP, 553 F.3d 609, 630 (8th Cir. 2009) ("Reasonable or justifiable reliance is an element of both fraud and negligent misrepresentation.... [T] he language of the Participation Agreement effectively negates the justifiability of Bremer's reliance on M\&S's or Dorsey's representations."). But see Sisneros v. Citadel Broad. Co., 142 P.3d 34, 41 (N.M. Ct. App. 2006) ("[T] he existence of Plaintiff's duty to read the agreement before signing it does not end the inquiry. Plaintiff has produced evidence giving rise to factual inferences that could reasonably support the determination that his failure to read the agreement was justified by Citadel's conduct").

120 RESTATEMENT (SECOND) OF TORTS $\$ 918(1)$ provides that "one injured by the tort of another is not entitled to recover damages for any harm that he could have avoided by the use of reasonable effort or expenditure after the commission of the tort." It does, however, permit recovery where "the tortfeasor intended the harm ... unless the injured person with knowledge of the danger of the harm intentionally or heedlessly failed to protect his own interests."

The mitigation principle may have been the intuition underlying the California Supreme Court's decision in Edwards. See supra text beginning at note 94 . Given Mr. Edwards's position that the waiver of his right to indemnity was unenforceable, perhaps mitigation required him to sign the release. In this context, reliance and mitigation tend to blend.

121 Professor Kuklin views punitive damages as "the crux of a general solution" to the problem of unenforceable clauses, supra note 4 , at 892 , although even writing in 1988 , he recognized doctrinal problems. Id. at 892-94. Radical developments in the law of punitive damages since his article have compounded those difficulties. See generally Mark A. Geistfeld, Punitive Damages, Retribution, and Due Process, 81 S. CAL. L. REv. 263, 292-96 (2008); Anthony J. Sebok, Punitive Damages: From Myth to Theory, 92 IOWA L. REV. 957, 991-1002 (2007). 
rescinding a contract due to misrepresentation are looser than those required in tort for a misrepresentation to be actionable in deceit. ${ }^{122}$

In short, the traditional common law role has been essentially hands off with regard to the kinds of clauses we have surveyed. There are a scattering of other reactions to related problems but none that address the precise problem with which we are dealing. For example, some government agencies have engaged in essentially an educational function with regulations indicating that some prospective waivers of rights are unenforceable, ${ }^{123}$ which should at least reduce the numbers of those who are deceived. ${ }^{124}$ However, such regulations are not always issued, ${ }^{125}$ and, in any event, they tend to simply reinforce the message of contract law that the offending clause will not be enforced.

Another possibility is crafting statutes to provide that insistence on unenforceable clauses is itself illegal. A few scattered instances exist of this, including consumer protection statutes aimed at overreaching in residential real estate leases. ${ }^{126} \mathrm{~A}$ recent example in the employment context is the new

122 The requirements for misrepresentation as a basis for invalidating contracts tend to be less strict than those required to hold the other party affirmatively liable. One obvious difference is that the misrepresentation need be either fraudulent or material for the victim to void the contract, while tort law requires both fraud and materiality. Compare RESTATEMENT (SECOND) OF CONTRACTS § 164(1) (1981) ("If a party's manifestation of assent is induced by either a fraudulent or a material misrepresentation by the other party upon which the recipient is justified in relying, the contract is voidable by the recipient."), with RESTATEMENT (SECOND) OF TORTS $\$ 531$ (requiring an expectation that the misrepresentation will influence the other's conduct).

${ }^{123}$ E.g., Taylor v. Progress Energy, Inc., 493 F.3d 454, 458 (4th Cir. 2007) (reading Department of Labor regulation to bar both prospective and retrospective waiver of Family \& Medical Leave Act rights). The regulation in question at the time simply barred waivers. 29 C.F.R. $\$ 825.220$ (d) (2007). It has since been amended to bar "prospective" waivers. 29 C.F.R. $\$ 825.220$ (d) (2009). Both versions also provide, "nor may employers induce employees to waive, their prospective rights under FMLA," but it is not clear how the Department of Labor would sanction such inducement.

124 Even if the primary beneficiaries do not pore over the Code of Federal Regulations, unions and employee-oriented websites might widely disseminate such information. For example, googling "waiver of FMLA rights" brought up several sources, the first of which reported that such rights were not waivable. Search conducted on Sept. 8 , 2008. Ironically, the second source was the Jackson Lewis website, available at $\mathrm{http} / / / \mathrm{www}$.jacksonlewis.com/legalupdates/article.cfm?aid=822.

125 See Evan Hudson-Plush, Note, WARN's Place in the FLSA/Employment Discrimination Dichotomy: Why a Warning Cannot Be Waived, 27 CARDOZO L. REV. 2929, 2932-33 (2006) (neither the Workers Adjustment and Retraining Notification Act nor the Department of Labor implementing regulations deal with the question of waivers).

126 See supra note 5. 
Colorado Wage Transparency Act (WTA), ${ }^{127}$ which is designed to prevent employers from restricting the ability of their workers to discuss their compensation. ${ }^{128}$ Not only does the statute declare it illegal to take an adverse action against an employee for engaging in the protected conduct of discussing compensation but it also declares it illegal "to require an employee to sign a waiver or other document that purports to deny an employee the right to disclose his or her wage information." 129 Under the WTA, then, an employee who refuses to agree to keep her compensation confidential has an explicit remedy should the employer discharge her for that action.

Other statutes may be interpreted to reach a similar result when the employer takes an adverse employment action in response to the employee's protected conduct. For example, firing an employee for refusing to sign an agreement purporting to waive her antidiscrimination rights would seem to violate the antiretaliation provisions of various antidiscrimination statutes, which generally bar retaliation because an employee or applicant "has opposed any practice made an unlawful employment practice by this subchapter...";130 refusals to waive rights conferred by the statute would seem to qualify.

127 Colo. Rev. STAT. § 24-34-402 (2008).

${ }^{128}$ A few other states have similar laws. CAL. LAB. CODE $\S \S 232,232.5$ (2003); 820 ILl. COMP. STAT. ANN. 112/10(b) (2004); MICH. COMP. LAWS ANN. $\S 408.483 a(13 a)(1)$ (1999); Employer prohibitions of wage discussion have long been held to be prohibited by the National Labor Relations Act [hereinafter NLRA] for those workers within its coverage. 29 U.S.C. § 152(3) (2006). See, e.g., NLRB v. Main St. Terrace Care Ctr., 218 F.3d 531, 538 (6th Cir. 2000) (employer's oral rule prohibiting employees from discussing wages, though unenforced, could be reasonably perceived as coercive and thus interferes with employees' right to engage in protected concerted activity). Since it covers most private sector employment, the NLRA is far broader than the Colorado statute, although the latter protects employees who are not covered by the federal law, such as managers. COLO. REV. STAT. § 24-34-402(1)(h)(II)(i). See generally Leonard Bierman \& Rafael Gely, Love, Sex, and Politics. Sure. Salary? No Way, 25 BERKELEY J. EMP. \& LAB. L. 167, 171 (2004); Rafael Gely \& Leonard Bierman, Pay Secrecy/Confidentiality Rules and the National Labor Relations Act, 6 U. PA. J. LAB. \& EMP. L. 121, 124 (2003); Brian O'Neill, Pay Confidentiality: A Remaining Obstacle to Equal-Pay Post-Ledbetter, SETON HALl L. REV. (forthcoming).

129 COLO. REV. STAT $§ 24-34-402(1)(h)(I I)(i)$. Somewhat analogous is the Employee Polygraph Protection Act, 29 U.S.C. $\S \S 2001-2009$ (2006), which not only bars requiring an employee to take a polygraph but also prohibits a request that the employee do so. Id. $\S 2002$ ("it shall be unlawful for any employer ... (1) directly or indirectly, to require, request, suggest, or cause any employee or prospective employee to take or submit to any lie detector test.").

130 Section 704(a) of Title VII, 42 U.S.C. $\$ 2000 \mathrm{e}-3$ (a) (2006). The statute also bars retaliation because the employee "has made a charge, testified, assisted, or participated in 
Another, more generalized, possibility would be to hold the use of unenforceable clauses actionable under the wrongful discharge tort. Firing (or refusing to hire) someone for refusing to agree to an unenforceable clause is a good example. While there is relatively little case law supporting this approach, the California Supreme Court recently reaffirmed the principle. In Edwards v. Arthur Andersen $L L P,{ }^{131}$ the court was confronted with a situation in which an employee was not hired by a successor employer because he refused to agree to waive his rights under state law against his prior employer. At issue were both his right to compete after his employment ended and his statutory right to indemnity. ${ }^{132}$ With respect to the noncompetition clause, California's Business and Professions Code generally bars "every contract by which anyone is restrained from engaging in a lawful profession, trade, or business of any kind," 133 and $E d w a r d s$ is best known for its reaffirmation of the strength of California's policy against postemployment restraints of trade. ${ }^{134}$

any manner in an investigation, proceeding, or hearing under this subchapter." Id. See generally CHARLES A. SUlLIVAN \& LAUREN WALTER, EMPLOYMENT DisCRIMINATION LAW \& Practice (2008). Parallel language is found in the Age Discrimination in Employment Act, 29 U.S.C. $\$ 623$ (d) (2006), which has been read to largely track Title VII. See Gomez-Perez v. Potter, 128 S. Ct. 1931, 1940 (2008) (reading the federal employee provisions of the ADEA as coextensive with those of Title VII), and in the Americans with Disabilities Act, 42 U.S.C. $\$ 12203$ (2006), although the latter is framed more broadly. SULLIVAN \& WALTER, supra, $\S 11.09$. Section 1981 also has been read to bar retaliation for exercising the right to be free of racial discrimination in contracts. CBOCS W., Inc. v. Humphries, 128 S. Ct. 1951, 1957 (2008).

131189 P.3d 285, 289 (Cal. 2008).

132 Although the principles seem clear, Edwards arose from a complicated factual setting stemming from the sell-off of Arthur Andersen's practice groups in the wake of its indictment in connection with the Enron scandal. HSBC wanted to acquire the group for which Edwards worked, and Andersen agreed to release him if he signed a "termination of non-compete agreement." Part of this "TONC" released Andersen from claims by the employee. This agreement, of course, would be unnecessary if the noncompetition clause were invalid. In any event, HSBC made Edwards an offer of employment conditional on signing the TONC, but Edwards refused to sign. He believed the release required him to give up his right to indemnification against Andersen, a right that he thought especially critical because of the probability that former clients would sue Andersen and name him as a defendant. Because of this refusal, HSBC did not hire him. He then sued Andersen for intentional interference with prospective advantage; he also named HSBC, but settled with it.

133 CAL. BuS. \& PROF. CODE $\S 16600$ (2008). There are some statutory exceptions, most importantly in connection with the sale of a business, but none that reaches normal employees. Id. $\S 16601$.

134 See Mark A. Lemley \& James H.A. Pooley, California Restrictive Employment Covenants after Edwards, Nov. 4, 2008, available at http://papers.ssm.com/sol3/papers.cfm?abstract_id=1295606 (Nov. 4, 2008). 
But potentially as significant was the Edwards court's recognition that discharging an employee for refusing to waive an unwaivable right to indemnity would give rise to a cause of action under the state's public policy tort. Edwards, however, found no violation in the case before it because it read the waiver in question (from "any and all" claims, including "claims that in any way arise from or out of, are based upon or relate to Employee's employment by, association with or compensation from" the employer ${ }^{135}$ ) to not sufficiently specifically embrace the unwaivable right in question. Nevertheless, the principle is clear and would apparently apply to a refusal to hire, or discharge, an employee for not agreeing to an invalid noncompetition clause. ${ }^{136}$ Further, this approach may well be generalized: after some wavering on waiver, the draft Restatement (Third) of Employment Law included within its framing of the public policy tort disciplining an employee for refusing to waive a nonwaivable right. ${ }^{137}$

Nevertheless, Edwards does not render the mere inclusion of such a clause actionable. To quote an employer-oriented update, "Under the Supreme Court's holding in Edwards, if a claim is unwaivable, it cannot be waived; an employer's request for release of an unwaivable claim is therefore simply a nullity, not a tort."138 To violate the law, the employer must go a step further and take an adverse action against the employee for refusing to execute such a waiver. This is consistent with the scattered authority under the antidiscrimination laws refusing to find the mere insertion of clauses purporting to waive nonwaivable rights to be actionable retaliation. ${ }^{139}$

135 Edwards, 189 P.3d at 289.

136 Richard Bales, Sullivan on Not Waiving the Unwaivable, Jan. 17, 2009, http://lawprofessors. typepad.com/laborprof_blog/2009/01/sullivan-on-not.html.

${ }^{137}$ Section 4.02 provides: "An employer is subject to liability in tort under $\$ 4.01$ for disciplining an employee who acting in a reasonable manner ... (d) refuses to waive an unwaivable right or agree to an unenforceable condition under an employment statute or law ... " (Council Draft No. 3). Earlier drafts also barred employer retaliation because an employee refused to waive an unwaivable right arising from employment (Council Draft No. 2), but an intermediate version temporarily omitted this provision. The Reporters Notes for Council Draft 3 cite Edwards as holding that refusal to sign an invalid noncompetition agreement is not a basis for discharge in California, which suggests that Edwards is responsible for the resurrection of this category of protected conduct. The Restatement uses as Illustrations the two situations involved in that case: the employer fires someone for refusing to waive unwaivable employment-related rights (14) and for refusing to sign an unenforceable noncompetition clause (17).

138 White \& Case, California Litigation Report, Sept. 2008, http://www.whitecase.com/californialitigation_0908_1/

139 See EEOC v. Sundance Rehab. Corp., 466 F.3d 490, 501 (6th Cir. 2006) (no facial violation of anti-retaliation provisions in severance pay agreement conditioned on not filing charges with the EEOC). 
A final possible way to deal with the problem is to hold that attorneys who draft such clauses violate their professional responsibilities. ${ }^{140}$ Scholars who have taken the attorney regulation route have urged this approach in several contexts. For example, Professor Martin Malin argued that attorneys should be held accountable for drafting invalid arbitration agreements, ${ }^{141}$ although his claim is "normative rather than positive." 142 To the extent such arguments are predicated on positive law, they look to Model Rule 1.2(d): "[A] lawyer shall not... [c]ounsel or assist his client in conduct that the lawyer knows to be illegal or fraudulent." 143 However, when arguing that this language might literally encompass drafting an "illegal" agreement, Malin recognizes that "the Code was never interpreted to apply to conduct that was neither criminal nor fraudulent."144 Professor Malin addresses only in passing the possibility that insisting on an agreement that is unenforceable

${ }^{140}$ In other contexts, this could be referred to as gatekeeper liability. See generally John C. Coffee, Jr., The Attorney as Gatekeeper: An Agenda for the SEC, 103 COLUM. L. REV. 1293, 1310-15 (2003). But efforts to impose liability on attorneys or accountants, or personal liability on officers and directors, tend to be derivative of the liability that would attach to the corporation itself. In the situation with which we are dealing, there is little risk of such corporate liability. See Timothy P. Glynn, Beyond "Unlimiting" Shareholder Liability: Vicarious Tort Liability for Corporate Officers, 57 VAND. L. REV. 329, 359 (2004).

141 Martin H. Malin, Ethical Concerns in Drafting Employment Arbitration Agreements After Circuit City and Green Tree, 41 BRANDEIS L.J. 779, 813-16 (2003); see also Stephen L. Pepper, Counseling at the Limits of the Law: An Exercise in the Jurisprudence and Ethics of Lawyering, 104 YALE L.J. 1545, 1592-93 (1995).

142 Malin, supra note 141 at 803 . But see Bauer, supra note 32 (arguing that seeking certain confidentiality clauses in settlement agreements violate attorney ethics).

143 Professor Kuklin was less cautious:

The offeree may be able to sue the attorney directly for deceit or other torts whether he is an agent, or an independent contractor. The attorney's liability, direct or indirect, is not unfairly burdensome. Already he or she is held to high standards in advising clients of the law; the legal "advice" to the client's client's adversary requires no additional knowledge by the attorney. It is simply a matter of expressing that knowledge nonfraudulently.

Kuklin, supra note 4, at 897-98. Despite this statement, the notion that an attorney for one party may be liable to the opposing party for inserting unenforceable clauses would be a dramatic shift in the role of the attorney in the United States.

144 Malin, supra note 141, at 817; see Renfroe v. Jones \& Assocs., 947 S.W.2d 285, 288 (Tex. App. 1997) ("Under Texas law, attorneys cannot be held liable for wrongful litigation conduct. A contrary policy 'would dilute the vigor with which Texas attorneys represent their clients' and 'would not be in the best interests of justice."') (citations omitted). See generally Alex B. Long, Attorney Liability for Tortious Interference: Interference with Contractual Relations or Interference with the Practice of Law? 18 GEO. J. LEGAL ETHICS 471 (2005). 
might be fraudulent within the meaning of Rule 1.2(d), but this alternative also seems unlikely for reasons we explored previously.

\section{RETHINKING JUDICIAL HANDS-OFF}

If unenforceable-as-written clauses are a problem because of the law of contracts (even of misperceptions of that law), perhaps it is that law which ought to provide the solution. To do so, however, will require a change in a long-standing paradigm. Courts have generally conceived their role in enforcing contracts to be putting the power of the law behind whatever private ordering meets some very permissive criteria. They insist on an agreement and on consideration or a substitute. ${ }^{145}$ They also, albeit grudgingly, require a writing where the statute of frauds so commands. ${ }^{146}$ There are doctrines designed to insure that the parties to the agreement are competent, ${ }^{147}$ and doctrines designed to prevent agreements that are the result of misrepresentation ${ }^{148}$ or other improper conduct like duress, ${ }^{149}$ undue influence, ${ }^{150}$ and unconscionability. ${ }^{151}$ But once an agreement passes these various, large-grained screens, the courts generally seem to feel compelled to enforce it. ${ }^{152}$

145 RESTATEMENT (SECOND) OF CONTRACTS, $§ 17$ (1981) (" $[T]$ he formation of a contract requires a bargain in which there is a manifestation of mutual assent to the exchange and a consideration.").

146 It is generally accepted that the courts interpret statutes of frauds narrowly. E.g., C. R. Klewin, Inc. v. Flagship Props., Inc., 600 A.2d 772, 775-76 (Conn. 1991) ("[T]he one-year provision no longer seems to serve any purpose very well, and today its only remaining effect is arbitrarily to forestall the adjudication of possibly meritorious claims. For this reason, the courts have for many years looked on the provision with disfavor, and have sought constructions that limited its application.").

147 RESTATEMENT (SECOND) OF CONTRACTS $§ 12$.

148 See supra text accompanying note 117.

149 RESTATEMENT (SECOND) OF CONTRACTS $\S \S 174-76$ (1981).

150 Id. $\$ 177$.

${ }^{151}$ Id. \$208. It may be significant that the Restatement's version of unconscionability is placed in the section on The Scope of Contractual Obligations, suggesting less an invalidation of the entire contract than a tailoring of it to avoid overreaching by one party.

152 Sometimes courts will limit the remedies for breach to reflect other social policies. Most obviously, the courts may deny specific performance on equitable grounds, Kilarjian v. Vastola, 877 A.2d 372, 376-77 (N.J. Sup. Ct. 2004) (refusing to order specific performance of a land sale contract where the result would be to remove a sick woman from her home), but there are also situations where damages may be limited by concerns of fairness or efficiency. E.g., Jacob \& Youngs, Inc. v. Kent, 129 N.E. 889, 891 
This is most obviously reflected in the debates about "severability"153 and modifying facially invalid terms ${ }^{154}$ which we briefly encountered earlier. Conceptually, the two approaches are really one, although some courts view modification as part of the severability analysis ${ }^{155}$ and others seem to treat it as simply an exercise of equitable power. ${ }^{156}$ Whatever the framing, once a court determines that a clause is unenforceable as written, it then needs to decide whether the clause (a) can be modified to be valid and (b), if not, whether to enforce the remainder of the contract without the clause. ${ }^{157}$ Contract law tends to be permissive on both points. The starting place is Section 184 of the Second Restatement of Contracts, which has two relevant paragraphs. The first is not problematic, merely permitting enforcement of "the rest of the agreement in favor of a party who did not engage in serious misconduct if the performance as to which the agreement is unenforceable is not an essential part of the agreed exchange."158 This provision obviously tends to protect the imposed-upon party. ${ }^{159}$ The second paragraph of Section 184, however, allows a court to "treat only part of a term as unenforceable ... if the party who seeks to enforce the term obtained it in good faith and in accordance with reasonable standards of fair dealing."160

The Restatement, therefore, applies a nuanced approach which seeks to preserve contracts to the maximum extent possible. The innocent party will not lose the benefit of any contract unless the invalid provision is "an

(N.Y. 1921) (choosing a diminution in value measure of damages as opposed to cost of repair in order to avoid "economic waste").

153 See supra note 94.

154 See supra note 102.

155 E.g., A.N. Deringer, Inc. v. Strough, 103 F.3d 243, 248 (2d Cir. 1996).

156 E.g., Bess v. Bothman, 257 N.W.2d 791 (Minn. 1977).

157 See generally Mark L. Movsesian, Severability in Statutes and Contracts, 30 GA. L. REV. 41 (1995) (arguing against the use of contract principles on severability to statutes containing unconstitutional provisions).

158 RESTATEMENT (SECOND) OF CONTRACTS $§ 184(1)$ (1981).

159 The analogy is obviously to a contract that is voidable by the victim of misrepresentation. In such cases, however, there is a right to either enforce or void the contract. In the situation with which we are dealing, RESTATEMENT (SECOND) OF CONTRACTS $\S 184(2)$ makes clear that the injured party has no absolute right to escape the contract merely because it is defective in some respect.

160 RESTATEMENT (SECOND) OF CONTRACTS $\S 184(2)$; see also Wastak v. Lehigh Valley Health Network, 342 F.3d 281, 292 (3d Cir. 2003) (the mere presence of an unenforceable ban on filing a charge with the EEOC does not void a waiver); EEOC v. Cosmair, Inc., 821 F.2d 1085, 1091 (5th Cir. 1987) ("[T] charge is void does not invalidate a waiver of a cause of action with which it is conjoined."). 
essential part of the agreed exchange," 161 and even the guilty party will not necessarily lose protection of the rest of the contract if it did not engage in "serious misconduct" and was reasonable and in good faith. ${ }^{162}$

Whether a term was an essential part of the agreed exchange can be answered in part by whether the contract included a clause providing for severability, which will be influential but not determinative. ${ }^{163}$ In either event, the courts may look to the extrinsic evidence, including negotiating history and business context, to decide whether the parties would have entered into the contract absent the term. ${ }^{164}$ The ultimate test, apparently, is what the parties would have done had they known that the term would not be enforced. ${ }^{165}$ This seems to follow from the nature of contracts itself, which are enforced to implement the intentions of the parties. Having found a part of the contract unenforceable for public policy reasons, the courts-in theory at least - ask the counterfactual question of whether, had the parties been correctly informed at the outset, they would have wanted the rest of the contract to operate or whether they would have walked away from the deal. ${ }^{166}$

161 Professor Movsesian's study focuses almost exclusively on the "essential to the agreed exchange" aspect of the Restatement and does not consider the other limitations imposed. Movsesian, supra note 157, at 47-48.

162 This test is a compilation of the requirements of subsections (1) and (2) of RESTATEMENT (SECOND) OF CONTRACTS $\S 184$.

163 See Beilfuss v. Huffy Corp., 685 N.W.2d 373, 378 (Wis. Ct. App. 2004) (enforcing a contract with a severability clause despite holding a choice of law provision unenforceable).

${ }^{164}$ Zerbetz v. Alaska Energy Ctr., 708 P.2d 1270, 1283 (Alaska 1985); Eckles v. Sharman, 548 F.2d 905 (10th Cir. 1977).

165 See RESTATEMENT (SECOND) OF CONTRACTS $§ 183$ (1981), which provides that enforcement will not be denied where the respective performance "can be apportioned into corresponding pairs of part performances." In such case, the pairs of performances that do not implicate public policy are to be enforced "by a party who did not engage in serious misconduct." The relationship between Section 184's proscription of enforcement when the dominant party is in bad faith or unreasonable and Section 183's validation of enforcing corresponding pairs is not clear, but Comment $\mathrm{c}$ seems to suggest that that factor is irrelevant for corresponding pairs.

166 Presumably, when a court finds that an unenforceable provision is essential to the agreed exchange, the contract as a whole fails and the parties are left to restitutionary remedies for any benefits conferred on each other under it. Whether one party will be denied restitution because of something like "serious misconduct" might depend on the nature of the misconduct. See RESTATEMENT (THIRD) OF RESTTTUTION AND UNJUST ENRICHMENT $\S 32$ (Mar. 22, 2004) (Tentative Draft No. 3) (viewing restitution in the case of "illegality" as turning both on considerations of unjust enrichment and furtherance of the policies that make the contract illegal). 
This advances a policy of enforcing private ordering to the maximum extent possible, but it slights the public policy issues, which arise not from the parties' intent regarding the contract but rather from a need to discourage inappropriate agreements and/or judicial legitimacy concerns about not making courts complicit in the misconduct at issue. ${ }^{167}$ To these ends, Section 184(1) suggests by negative implication that neither party can enforce the contract at all if it did engage in serious misconduct, and Section 184(2) indicates that, perhaps even short of this level of wrongdoing, enforcement will be denied if the dominant party's conduct was not in good faith and in accordance with reasonable standards of fair dealing. ${ }^{168}$

In fact, it is not clear whether "serious misconduct" is different from the absence of good faith and reasonableness or a kind of shorthand for it. ${ }^{169}$ In any event, Section 184(2) sets out a dual standard: not only must the insisting party be in good faith (presumably a subjective standard) but must also satisfy "reasonable standards of fair dealing" (presumably an objective standard that looks to what others in similar situations do). Where the two standards are met, the court may enforce the remainder of the agreement by

${ }^{167}$ Indeed, judicial language often conflates the need to avoid the at-issue harm and the need to avoid involving the courts in such harm. Some language in early decisions suggests a desire to keep the courts themselves free of any taint: "[N]o polluted hand shall touch the pure fountains of justice." Collins v. Blantern, (1767) 2 Wils. 341, 350 (Wilmot, J.). Trying to unpack such a metaphor has its risks, see John W. Wade, supra note 16, at 31, 38-39 (focusing on the polluted hand or "bad man" aspect of this statement), but an equally important thrust seems to be the threat to the legitimacy of the courts when they assist bad men. Id. at 44-45 ("No Court will lend its aid to a man who founds his cause of action upon an immoral or illegal act," quoting Lord Mansfield in Holman v. Johnson, (1775) 98 Eng. Rep. 1120, 1121 (K.B.); see also John Shand, Unblinkering the Unruly Horse: Public Policy in the Law of Contract, 30 CAMBRIDGE L.J. 144, 150-52 (1972) (disapproving of this basis for invalidating agreements).

168 See Zerbetz, 708 P.2d at 1283.

${ }^{169}$ See supra note 165 (discussing relationship of Sections 183 and 184; the former section mentions serious misconduct but not good faith or reasonableness). 
severing the objectionable term or by severing (modifying) ${ }^{170}$ its objectionable parts. ${ }^{171}$

Under the Restatement, then, we end up with the best of both worlds-an agreement that, to the maximum extent possible, implements the intent of the parties while avoiding infringement on broader public policies. However, one may be rightly suspicious of just-so stories where the law really achieves so particular a perfection. In any event, the Restatement's blackletter does not reflect the way in which the courts approach the phenomenon. While the Restatement is subject to criticism both in its vagueness and in its failure to consider harm to parties not before the court, the real difficulty may be in the failure of the courts to apply the Restatement's approach with any rigor. In the two situations we have examined, there is rarely any judicial focus on the conduct of the dominant party in obtaining the clause. Thus, courts in the noncompete context never look to whether the dominant party was intentionally overreaching or used such clauses in standard forms to bind numerous employees. Interestingly, a comment to the Restatement views the inclusion of the clause on a standard form as pointing towards invalidation, ${ }^{172}$ but that provision has almost never been invoked. ${ }^{173}$ As for

170 That the Restatement views modification as a kind of severance is clear from the illustrations. Illustration 4 to Section 184 would permit the partial enforcement of an agreement exonerating A from "willful or negligent breach of duty" by allowing exoneration with respect to negligence. RESTATEMENT (SECOND) OF CONTRACTS $\S 184$ cmt. b, illus. 4 (1981). Illustration 5 would allow enforcement of a usurious interest rate "up to the highest permissible rate" if the offending rate was the result of a mistake. Id. $\S 184 \mathrm{cmt}$. b, illus. 5. "If $\mathrm{A}$ knew when he made the loan that the amount exceeded the highest permissible legal rate, B's promise to pay interest would be unenforceable in its entirety." Id.

171 Of course, it does not follow that the court will always do so. See Guercio v. Prod. Automation Corp., 664 N.W.2d 379, 385 (Minn. Ct. App. 2003) ("On these undisputed facts, we hold as a matter of law that the parties did not intend for the noncompete clause in the April 26 agreement to be severed from the commission clause.").

172 Comment a to Section 184 explains:

A court will not exercise this discretion in favor of a party unless it appears that he made the agreement in good faith and in accordance with reasonable standards of fair dealing. For example, a court will not aid a party who has taken advantage of his dominant bargaining power to extract from the other party a promise that is clearly so broad as to offend public policy by redrafting the agreement so as to make a part of the promise enforceable. The fact that the term is contained in a standard form supplied by the dominant party argues against aiding him in this request. (citations omitted).

RESTATEMENT (SECOND) OF CONTRACTS $\S 184 \mathrm{cmt}$. a (1981). Despite this Comment, there is little evidence that the term being on a standard form influences court decisions.

173 One of the few cases finding the use of a standard form a factor cutting against severance is Broadley v. Mashpee Neck Marina, Inc., 471 F.3d 272, 276 (1st Cir. 2006) 
the arbitration context, most cases simply sever the offending terms (or, perhaps even more problematically, remit that task to the arbitrator); however in a few cases, the courts find the invalid terms sufficiently egregious to taint the agreement to arbitrate. ${ }^{174}$

This Article essentially argues for renewed attention to adverse effects on parties not before the court in both areas (and with respect to other potential uses of clauses that are unenforceable as written). The current judicial paradigm focuses on the parties to the at-issue contract and seeks to enforce their agreement to the maximum extent possible once objectionable terms are stripped out. Another way of saying the same thing is that the courts attempt to do justice for the parties before them, which is achieved by enforcing their agreements once any terms are eliminated that adversely affect third parties or intrude more than the law allows into even the contracting parties' rights.

A better paradigm would consider the effects of such clauses on yet another set of third parties: those who sign contracts with invalid terms believing them to be valid and enforceable. The law currently creates perverse incentives by maximizing the benefits of seeking certain kinds of clauses (generalized compliance without the bother and expense of litigation) while minimizing the risks (by insuring at least half a loaf when a particular clause is challenged). It seems likely that the low level of risk in insisting on invalid terms results in many thousands of contracts containing such terms, contracts that will have adverse real world effects on their signatories because of information asymmetries. If this is true, the courts should shift gears. Rather than focusing on doing justice only to the parties before them, they should widen their perspectives to avoid becoming complicit in the injustices such clauses perpetrate on those not before the court. A determination that a noncompetition clause or arbitration agreement is invalid should result in a denial of the dominant party's suit to enforce it. ${ }^{175}$

This could be done as a matter of state law in all jurisdictions as far as noncompetition clauses are concerned. ${ }^{176}$ The question of whether courts

(striking down an overbroad exculpatory clause without narrowing it to include only negligence: "Any competent lawyer could write a straightforward exclusion of liability for negligence that we would sustain.").

174 See supra note 94.

175 Courts might even consider making such contracts entirely voidable at the request of the imposed-on party. The result would be to allow such a party, the employee in the cases we have been considering, to seek restitution for benefits conferred (her services) on the basis of market value, rather than the contract price, subject of course to an offset for any benefits (compensation) received.

176 The proposed Restatement of Employment Law cites an earlier draft of this article but nevertheless would allow modification of an "overbroad restrictive covenant" except when "the agreement itself bars modification, the employer lacked good faith in insisting on the covenant, or the covenant is sufficiently overbroad as to indicate that the 
may do so with overbroad arbitration agreements is more complicated because the Federal Arbitration Act controls. That statute, however, requires only that "[a] written provision... shall be valid, irrevocable, and enforceable, save upon such grounds as exist at law or in equity for the revocation of any contract."177 This applies a nondiscrimination principle with regard to arbitration, ${ }^{178}$ which means in turn that broader invalidation of noncompete clauses on the grounds suggested would go far towards justifying the same approach to arbitration agreements. But whether the arguments made in this Article go to "any contract," or just those risking the results detailed, might be questioned.

If a court were to take this approach, implementing it would not be difficult. The first step is, as is already true, to determine whether the clause, properly interpreted, is permissible. If the answer is no, the courts should ask whether the clause is in general use by the employer. An affirmative answer to that question should weigh heavily towards invalidating the entire contract although the court may nevertheless enforce the clause as modified if it is satisfied that the dereliction is truly minor and unintentional. Even in those cases, the court should condition any enforcement on the employer notifying others subject to the same or similar clauses of the court's decision.

Perhaps counterintuitively, the use of such clauses by others in the industry should not cut in favor of enforcement. The fact that such clauses are rare in a particular sector should cut against enforcement since this suggests that they are not necessary. But widespread use of noncompetition clauses is actually a factor cutting against enforcement because the harms of walling off competition in such a setting are greater. ${ }^{179}$

\section{CONCLUSION}

This Article has called for a reconsideration of the willingness of courts to partially enforce clauses in which one party has overreached what the law allows. It is predicated on the notion that such overreaching is often, perhaps typically, standard operating procedure for many employers precisely

employer lacked good faith." RESTATEMENT OF EMPLOYMENT LAW $\S 8.08$ (Oct. 8, 2009) (Council Draft No. 4).

1779 U.S.C. $\$ 2$ (2006).

178 Southland Corp. v. Keating, 465 U.S. 1 (1984) (invalidating state law requiring a judicial forum for certain kinds of claims). See generally David S. Schwartz, Correcting Federalism Mistakes in Statutory Interpretation: The Supreme Court and the Federal Arbitration Act, 67 LAW \& CONTEMP. PROBS. 5 (2004); David S. Schwartz, The Federal Arbitration Act and the Power of Congress over State Courts, 83 OR. L. REV. 541 (2004).

179 See generally Charles A. Sullivan, Revisiting the "Neglected Stepchild": Antitrust Treatment of Postemployment Restraints of Trade, 1977 U. ILL. L.F. 621, 64750 . 
because the law does not provide adequate incentives to try to comply with its mandates. The harm of such overreaching typically falls on parties not before the court, which renders myopic the judicial focus on doing justice to the parties to the contract that happen to be before the court. A major consideration in the relief a court accords once it determines a particular clause is not enforceable as written is the extent to which the employer uses the clause to achieve goals that the law disallows.

This solution, admittedly, has its limits. Even assuming that a court would strike a noncompetition or arbitration clause in its entirety when it would have enforced a more appropriately drafted provision, an employer with a large number of workers might still find it in its interests to insist on invalid clauses - if the vast majority of those workers believed the contracts to be valid or were too risk-averse to consider a challenge. An additional remedy might be an order to the offending employer to inform all parties to such contracts of the court's decision invalidating them. A further limitation on the effectiveness of the approach urged here is the possibility that courts are tailoring noncompetes rather than striking them down in part to avoid the need for addressing complicated trade secret issues. ${ }^{180}$ If that is true, even invalidation of an entire clause does not mean that no restraint will be imposed - unless the courts go further and withhold enforcement of trade secret rights because of employer overreaching.

180 See supra note 65. 
